\title{
Degradation of Micropollutants and Formation of Oxidation By-Products during the Ozone/Peroxymonosulfate System: A Critical Review
}

\author{
Zhao Liu ${ }^{1,2}$, Zhiting Liang ${ }^{1,2}$, Kai Li ${ }^{1,2}{ }^{D}$, Tinglin Huang ${ }^{1,2}$, Jun Ma ${ }^{3}$ and Gang Wen ${ }^{1,2, *(D)}$ \\ 1 Key Laboratory of Northwest Water Resource, Environment and Ecology, MOE, Xi'an University of \\ Architecture and Technology, Xi'an 710055, China; lz@xauat.edu.cn (Z.L.); Liangzhiting12@163.com (Z.L.); \\ likai@xauat.edu.cn (K.L.); huangtinglin@xauat.edu.cn (T.H.) \\ 2 Shaanxi Key Laboratory of Environmental Engineering, Xi'an University of Architecture and Technology, \\ Xi'an 710055, China \\ 3 State Key Laboratory of Urban Water Resource and Environment, Harbin Institute of Technology, \\ Harbin 150090, China; majun@hit.edu.cn \\ * Correspondence: hitwengang@163.com; Tel.: +86-29-82207886; Fax: +86-29-82201354
}

check for updates

Citation: Liu, Z.; Liang, Z.; Li, K.; Huang, T.; Ma, J.; Wen, G. Degradation of Micropollutants and Formation of Oxidation By-Products during the Ozone/ Peroxymonosulfate System: A Critical Review. Water 2021, 13, 3126. https:/ /doi.org/10.3390/w13213126

Academic Editors: Minghao Sui and Tian Li

Received: 9 October 2021

Accepted: 3 November 2021

Published: 5 November 2021

Publisher's Note: MDPI stays neutral with regard to jurisdictional claims in published maps and institutional affiliations.

Copyright: (c) 2021 by the authors. Licensee MDPI, Basel, Switzerland. This article is an open access article distributed under the terms and conditions of the Creative Commons Attribution (CC BY) license (https:/ / creativecommons.org/licenses/by/ $4.0 /)$.

\begin{abstract}
The $\mathrm{O}_{3} / \mathrm{PMS}$ system has appeared as an effective wastewater treatment method because of the simultaneous generation of hydroxyl radicals $\left({ }^{\bullet} \mathrm{OH}\right)$ and sulfate radicals $\left(\mathrm{SO}_{4}{ }^{\bullet-}\right)$. Many research achievements have been made on the degradation of micropollutants and the reaction mechanism of the $\mathrm{O}_{3} /$ PMS system. However, an integral understanding of the $\mathrm{O}_{3} / \mathrm{PMS}$ system is lacking, which limits the development of safe and effective AOP-based water treatment schemes. Therefore, in this review, the degradation effects, toxicity changes, and reaction mechanisms of various micropollutants in the $\mathrm{O}_{3} /$ PMS system are reviewed. The formation of oxidation by-products (OBPs) is an important issue that affects the practical application of $\mathrm{O}_{3} / \mathrm{PMS}$ systems. The formation mechanism and control methods of OBPs in the $\mathrm{O}_{3} / \mathrm{PMS}$ system are overviewed. In addition, the influence of different reaction conditions on the $\mathrm{O}_{3} / \mathrm{PMS}$ system are comprehensively evaluated. Finally, future research needs are proposed based on the limited understanding of $\mathrm{O}_{3} / \mathrm{PMS}$ systems in the degradation of micropollutants and formation of OBPs. Specifically, the formation rules of several kinds of OBPs during the $\mathrm{O}_{3} /$ PMS system are not completely clear yet. Furthermore, pilot-scale research, the operational costs, sustainability, and general feasibility of the $\mathrm{O}_{3} / \mathrm{PMS}$ system also need to be studied. This review can offer a comprehensive assessment on the $\mathrm{O}_{3} / \mathrm{PMS}$ system to fill the knowledge gap and provide guidance for the future research and engineering applications of the $\mathrm{O}_{3} /$ PMS system. Through this effort, the $\mathrm{O}_{3} /$ PMS system can be better developed and turned towards practical applications.
\end{abstract}

Keywords: ozone; peroxymonosulfate; micropollutants; oxidation by-products

\section{Introduction}

At present, the emergence of some pollutants (such as drugs, personal care products, endocrine disruptors, and other refractory organics) pose a threat to water quality and safety, which has aroused widespread concern [1-3]. Sulfate radicals $\left(\mathrm{SO}_{4}{ }^{\bullet-}\right)$-based advanced oxidation processes (AOPs) have received widespread attention owing to their strong oxidation ability, fast reaction rate, and wide applicability to contaminants in wastewater [4-6]. $\mathrm{SO}_{4}{ }^{\bullet-}$ can be obtained by activation of PMS through various methods, which include ultraviolet light (UV) irradiation, heating, or addition of transition metals, carbon materials and ozone $\left(\mathrm{O}_{3}\right)$ [4,7-9]. As a strong oxidant, $\mathrm{O}_{3}$ can activate PMS to produce $\mathrm{SO}_{4}{ }^{\bullet-}$, while at the same time it will decompose to produce a large amount of hydroxyl radicals $\left({ }^{\bullet} \mathrm{OH}\right)$ [10-12]. In addition, singlet oxygen $\left({ }^{1} \mathrm{O}_{2}\right)$ and superoxide radicals $\left(\mathrm{O}_{2}{ }^{\bullet-}\right)$ also can be generated in the process of $\mathrm{O}_{3}$ activating PMS $[13,14]$. Under the combined action of these reactive oxygen species (ROS), different types of micropollutants can be 
efficiently degraded. Specifically, the results of studies showed that $\mathrm{O}_{3} / \mathrm{PMS}$ achieved $81 \%$ removal of ATZ in $10 \mathrm{~min}$ [10], and PMT was eliminated by $99.27 \%$ approximately in $\mathrm{O}_{3} /$ PMS system within 10 min [15], while $p$ CBA was fully degraded by $\mathrm{O}_{3} /$ PMS in less than $5 \mathrm{~min}$ [16]. Furthermore, Gholikandi et al. reported that in terms of sludge stabilization and dewatering, $\mathrm{O}_{3} /$ PMS was a better choice than other processes (i.e., $\mathrm{O}_{3}, \mathrm{O}_{3} / \mathrm{H}_{2} \mathrm{O}_{2}$, $\mathrm{O}_{3} /$ PS) [17]. The study of Andrés et al. indicated that the $\mathrm{O}_{3} / \mathrm{PMS}$ combination produced a synergistic effect in the inactivation of microorganisms [18]. All these studies have shown that the $\mathrm{O}_{3} / \mathrm{PMS}$ system has a very great application potential in water treatment.

However, ROS will unavoidably react with co-existing substances in aqueous solution, leading to the generation of large amounts of oxidation by-products (OBPs). The formation and control of OBPs is an important issue that has been relatively neglected in the study of AOPs. The common OBPs in AOPs-treated water include: (1) low-molecular-weight carbonyls (LMWCs) (e.g., carboxylic acids, benzoic compounds, aldehydes, ketones, ketoacids), (2) organic halogenated OBPs (X-OBPs) (e.g., trihalomethane (THM), haloacetic acids (HAA), chloral hydrate $(\mathrm{CH}))$, and (3) inorganic OBPs (e.g., nitrite $\left(\mathrm{NO}_{2}{ }^{-}\right)$, chlorite $\left(\mathrm{ClO}_{2}{ }^{-}\right)$, chlorate $\left(\mathrm{ClO}_{3}^{-}\right)$, and bromate $\left.\left(\mathrm{BrO}_{3}^{-}\right)\right)$[19-22]. Many of these low-molecular-weight carbonyls constitute assimilable organic carbon (AOC) easily, which can be rapidly utilized by microorganisms, leading to an increase in biomass [23,24]. In the United States, it is stipulated that chloroform (TCM), bromodichloromethane (BDCM), dibromochloromethane (DBCM), and bromoform (TBM) should be controlled below $80 \mu \mathrm{g} \cdot \mathrm{L}^{-1}$, and chloroacetic acid (CAA), bromoacetic acid (BAA), dichloroacetic acid (DCAA), dibromoacetic acid (DBAA), and trichloroacetic acid (TCAA)) should be controlled below $60 \mu \mathrm{g} \cdot \mathrm{L}^{-1}$ [25]. Both the World Health Organization (WHO) and China have issued individual guidelines for $\mathrm{ClO}_{2}{ }^{-}$and $\mathrm{ClO}_{3}{ }^{-}$, each of which should be below $700 \mu \mathrm{g} \cdot \mathrm{L}^{-1}$ in drinking water [26,27]. $\mathrm{BrO}_{3}{ }^{-}$is a class $2 \mathrm{~B}$ carcinogen stipulated by the WHO and the U.S. Environmental Protection Agency (USEPA), and $10 \mu \mathrm{g} / \mathrm{L}$ is set to be the maximum contaminant level of $\mathrm{BrO}_{3}{ }^{-}$in drinking water [27]. It should be noted that the difference between OBPs and disinfection by-products (DBPs) is only that the former is a kind of by-product of AOPs, and the latter is a kind of product of conventional disinfection (i.e., adding chlorine $\left(\mathrm{Cl}_{2}\right)$, monochloramine $\left(\mathrm{NH}_{2} \mathrm{Cl}\right)$, chlorine dioxide $\left.\left(\mathrm{ClO}_{2}\right)\right)[28,29]$. As an $\mathrm{AOP}$, the $\mathrm{O}_{3} / \mathrm{PMS}$ system will produce many kinds of OBPs during the process of treating micropollutants, which greatly limits the application of an $\mathrm{O}_{3} /$ PMS system in the actual water treatment.

In addition, the influence of different reaction parameters (e.g., concentration of reactive substances), reaction conditions (e.g., $\mathrm{pH}$, temperature), and water quality (e.g., concentration of inorganic and organic substances) on the reaction system is also one of the key points that needs to be studied urgently in AOPs. The results of several studies have shown that the concentration of $\mathrm{O}_{3}$ and PMS have an appropriate range. Excessive dosage of $\mathrm{O}_{3}$ and PMS would have a negative impact on the degradation of micropollutants in the $\mathrm{O}_{3} / \mathrm{PMS}$ system [30-32]. Temperature affects the decomposition of $\mathrm{O}_{3}$ and the activation of PMS [33-35]. In addition, $\mathrm{pH}$ also shows influence on the conversion of free radicals $[30,31,36]$. Inorganic ions (e.g., $\mathrm{Cl}^{-}, \mathrm{NO}_{2}{ }^{-}, \mathrm{CO}_{3}{ }^{2-}, \mathrm{HCO}_{3}{ }^{-}$, phosphate) usually inhibit the degradation of micropollutants in the $\mathrm{O}_{3} / \mathrm{PMS}$ system by scavenging free radicals [37-40]. Natural organic matter (NOM) in water acts as a promoter or inhibitor for the generation of free radicals [41-43]. Therefore, the influence of these external conditions on the $\mathrm{O}_{3} /$ PMS system needs to be comprehensively considered in both the analysis of the degradation effect of $\mathrm{O}_{3} / \mathrm{PMS}$ system on micropollutants and the study of the generation and control of OBPs in $\mathrm{O}_{3} /$ PMS system.

To the best of our knowledge, the current research on the $\mathrm{O}_{3} / \mathrm{PMS}$ system mainly focuses on the theoretical exploration of a single direction. There has been no specific review on the $\mathrm{O}_{3} /$ PMS system so far, which stimulated us to write this review article on this fast-growing research area with emphasis on the introduction, influence factors, degradation of micropollutants and formation and control of OBPs of $\mathrm{O}_{3} / \mathrm{PMS}$ system. The aim of this work is to develop an integrated understanding of the $\mathrm{O}_{3} / \mathrm{PMS}$ system through a critical evaluation of the relevant publications. As a result, the knowledge gaps 
in related research and future research directions are explored, so that the $\mathrm{O}_{3} / \mathrm{PMS}$ system can be better developed and used for practical applications.

\section{Background of the $\mathrm{O}_{3} / \mathrm{PMS}$ System}

\subsection{Proposal of the $\mathrm{O}_{3} / \mathrm{PMS}$ System}

As a strong oxidant, $\mathrm{O}_{3}$ can effectively degrade many organic substances which are refractory to traditional oxidation processes $[44,45]$. However, $\mathrm{O}_{3}$ has strong selectivity and tends to attack the double bonds, activated aromatic groups and non-protonated amines of organic substances [21,41]. On the other hand, ${ }^{\bullet} \mathrm{OH}$ produced in the process of $\mathrm{O}_{3}$ decomposition is a non-selective strong oxidant (Equations (1) and (2)), which can rapidly react with various micropollutants at nearly diffusion-controlled rates, and the diffusion-controlled rate of $\bullet \mathrm{OH}$ is $\sim 10^{8}-10^{10} \mathrm{M}^{-1} \mathrm{~s}^{-1}[46,47]$. Typically, the degradation of micropollutants by $\mathrm{O}_{3}$ is achieved by the combined activities of molecular $\mathrm{O}_{3}$ and ${ }^{\bullet} \mathrm{OH}$. However, the oxidation efficiency of $\mathrm{O}_{3}$ alone is very low for the refractory micropollutants in water due to the smaller amount of ${ }^{\bullet} \mathrm{OH}$ produced by $\mathrm{O}_{3}$ decomposition and the selectivity of molecular $\mathrm{O}_{3}$.

$$
\begin{gathered}
\mathrm{O}_{3}+\mathrm{OH}^{-} \rightarrow \mathrm{HO}_{2}{ }^{-}+\mathrm{O}_{2} 70 \mathrm{M}^{-1} \mathrm{~s}^{-1} \\
\mathrm{O}_{3}+\mathrm{HO}_{2}{ }^{-} \rightarrow \cdot \mathrm{OH}+\mathrm{O}_{2}{ }^{--}+\mathrm{O}_{2} 2.8 \times 10^{6} \mathrm{M}^{-1} \mathrm{~s}^{-1}
\end{gathered}
$$

The $\bullet \mathrm{OH}$-based AOPs have attracted widespread attention. The reaction between $\mathrm{O}_{3}$ and hydrogen peroxide $\left(\mathrm{H}_{2} \mathrm{O}_{2}\right)$ is one of the most common AOPs to produce ${ }^{\bullet} \mathrm{OH}$ for contaminant degradation [48]. The $\mathrm{O}_{3} / \mathrm{H}_{2} \mathrm{O}_{2}$ system was firstly proposed in a study by Staehelin and Hoigne [49]. Subsequently, the underlying mechanism of the $\mathrm{O}_{3} / \mathrm{H}_{2} \mathrm{O}_{2}$ system through quantum-chemical and thermokinetic analysis was revised [46,50]. $\mathrm{O}_{3}$ and $\mathrm{H}_{2} \mathrm{O}_{2}$ firstly react to form the adduct $\mathrm{HO}_{5}{ }^{-}$(Equation (3)), which subsequently decomposes in two ways (Equations (4) and (5)). Eventually, ${ }^{\bullet} \mathrm{OH}$ is generated through Equations (6)-(8).

$$
\begin{gathered}
\mathrm{HO}_{2}{ }^{-}+\mathrm{O}_{3} \rightarrow \mathrm{HO}_{5}{ }^{-} \\
\mathrm{HO}_{5}{ }^{-} \rightarrow \mathrm{O}_{3}{ }^{\bullet-}+\mathrm{HO}_{2} \\
\mathrm{HO}_{5}{ }^{-} \rightarrow 2 \mathrm{O}_{2}+\mathrm{OH}^{-} \\
\mathrm{O}_{3}{ }^{\bullet-} \rightleftharpoons \mathrm{O}^{\bullet}+\mathrm{O}_{2} \\
\mathrm{O}^{\bullet-}+\mathrm{H}_{2} \mathrm{O} \rightleftharpoons{ }^{\bullet} \mathrm{OH}+\mathrm{OH}^{-} \\
\mathrm{HO}_{2} \bullet \rightleftharpoons \mathrm{O}_{2}{ }^{\bullet-}+\mathrm{H}^{+} \\
\mathrm{O}_{2}{ }^{\bullet-}+\mathrm{O}_{3} \rightarrow \mathrm{O}_{3}{ }^{\bullet-}+\mathrm{O}_{2}
\end{gathered}
$$

$\mathrm{SO}_{4}{ }^{\bullet-}$, as a strong oxidant, has a higher selectivity and higher redox potential $\left(E_{0}=2.5-3.1 \mathrm{~V}\right)$ than ${ }^{\bullet} \mathrm{OH}$, and can react with many micropollutants at nearly diffusioncontrolled rates [51]. Additionally, compared with ${ }^{\bullet} \mathrm{OH}$, the reactions between $\mathrm{SO}_{4}{ }^{\bullet-}$ and micropollutants are less affected by alkalinity and NOM [51-53]. In many studies, the formation of $\mathrm{SO}_{4}{ }^{\bullet-}$ was achieved through activating persulfate (i.e., peroxodisulfate (PDS) and peroxymonosulfate (PMS)). The activation strategies include ultraviolet light (UV) irradiation, heating, or addition of transition metals and carbon materials [54-57]. The structure of PDS and PMS are shown in Figure 1. PMS has an asymmetric structure and a parallel peroxy bond $(\mathrm{O}-\mathrm{O})$ with $\mathrm{H}_{2} \mathrm{O}_{2}$, indicating that it is likely to substitute $\mathrm{H}_{2} \mathrm{O}_{2}$ by PMS in the $\mathrm{O}_{3} / \mathrm{H}_{2} \mathrm{O}_{2}$ system to achieve a synergistic effect [58]. Wen et al. reported that $\mathrm{O}_{3}$-activated PMS enhanced the degradation of $p C B A$, proving that PMS had a similar effect as $\mathrm{H}_{2} \mathrm{O}_{2}$ in promoting the generation of free radicals during ozonation [16]. Furthermore, the study of $\mathrm{Li}$ et al. theoretically demonstrated that high chemical reactivity and low kinetic stability of PMS prompted its reaction with $\mathrm{O}_{3}$ [13]. However, according to Figure 1 , PDS exists in the form of symmetric structure, where the peroxy group of it is stable and can hardly react with $\mathrm{O}_{3}$ [46]. The research by Yuan et al. also indicated that no radical 
signal was detected in the $\mathrm{O}_{3} / \mathrm{PDS}$ system [36]. Wen et al. reported that $\mathrm{O}_{3}$ decomposition was only slightly enhanced in the presence of PDS [16]. Therefore, extensive research has used $\mathrm{O}_{3}$ to activate $\mathrm{PMS}$ to generate ${ }^{\bullet} \mathrm{OH}$ and $\mathrm{SO}_{4}{ }^{\bullet-}$ simultaneously, which could quickly and effectively degrade a variety of micropollutants.

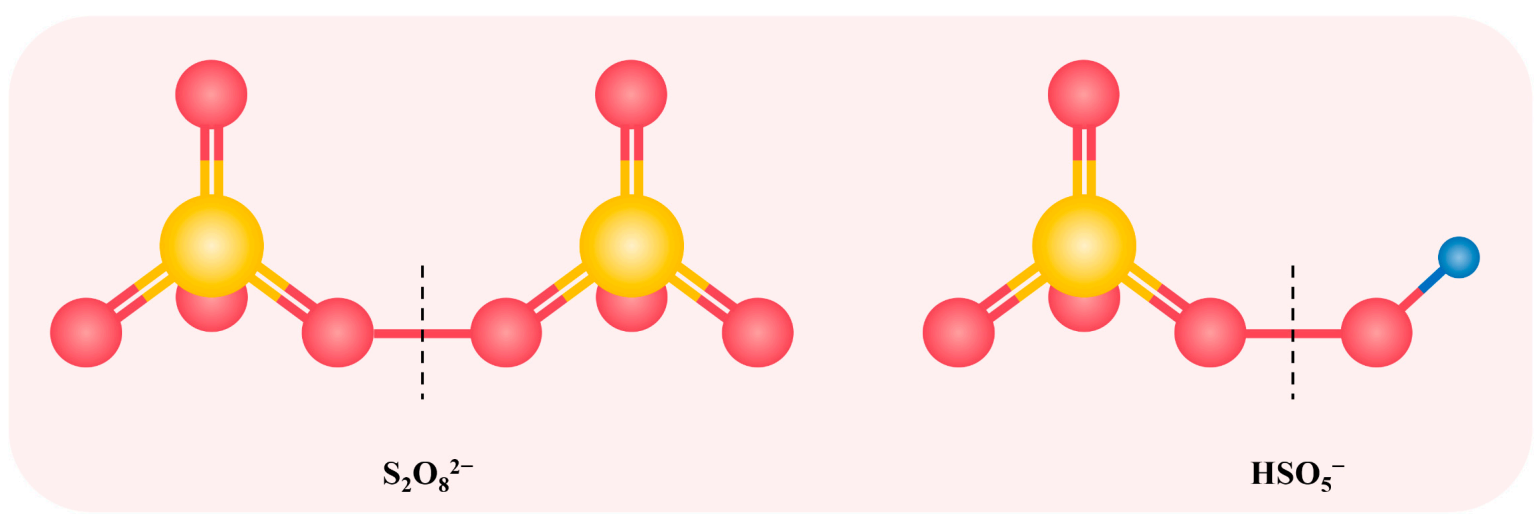

Figure 1. The structure of PDS and PMS. Yellow color is the sulfur atom and the red color is the oxygen atom. Dashed line represents the fission position of $\mathrm{O}-\mathrm{O}$ bond for the formation of sulfate radicals.

\subsection{Mechanism and Influencing Factors}

\subsubsection{Mechanism}

Yang et al. reported the mechanism of the simultaneous production of ${ }^{\bullet} \mathrm{OH}$ and $\mathrm{SO}_{4}{ }^{\bullet-}$ in the $\mathrm{O}_{3} / \mathrm{PMS}$ system [10]. The TBA assay and competition kinetics were used to determine the yields of ${ }^{\bullet} \mathrm{OH}$ and $\mathrm{SO}_{4}{ }^{\bullet-}$, respectively. As shown in Figure 2, $\mathrm{O}_{3}$ firstly reacted with $\mathrm{SO}_{5}{ }^{2-}$ (PMS) to produce ${ }^{-} \mathrm{O}_{3} \mathrm{SO}_{5}{ }^{-}$(Equation (10)), which is decomposed in two ways (Equations (11) and (12)). Next, $\mathrm{SO}_{5}{ }^{\bullet-}$ would further transform into $\mathrm{SO}_{4}{ }^{\bullet-}$ by reacting with $\mathrm{O}_{3}$ or decaying bimolecularly (Equations (13) and (14)), and $\mathrm{O}_{3}{ }^{\bullet-}$ would convert into ${ }^{\bullet} \mathrm{OH}$ (Equations (16) and (17)). Equations (12) and (15) are termination reactions with formation of $\mathrm{SO}_{4}{ }^{2-}$ and $\mathrm{S}_{2} \mathrm{O}_{8}{ }^{2-}$.

$$
\begin{gathered}
-\mathrm{O}_{3} \mathrm{SOO}^{-}+\mathrm{O}_{3} \rightarrow{ }^{-} \mathrm{O}_{3} \mathrm{SO}_{5}{ }^{-} 2.12 \times 10^{4} \mathrm{M}^{-1} \mathrm{~s}^{-1} \\
-\mathrm{O}_{3} \mathrm{SO}_{5}{ }^{-} \rightarrow \mathrm{SO}_{5}{ }^{--}+\mathrm{O}_{3}{ }^{\bullet-} \\
-\mathrm{O}_{3} \mathrm{SO}_{5}{ }^{-} \rightarrow \mathrm{SO}_{4}{ }^{2-}+2 \mathrm{O}_{2} \\
\mathrm{SO}_{5}{ }^{\bullet-}+\mathrm{O}_{3} \rightarrow \mathrm{SO}_{4}{ }^{\bullet-}+2 \mathrm{O}_{2} 1.6 \times 10^{5} \mathrm{M}^{-1} \mathrm{~s}^{-1} \\
2 \mathrm{SO}_{5}{ }^{--} \rightarrow 2 \mathrm{SO}_{4}{ }^{--}+\mathrm{O}_{2} 2.1 \times 10^{8} \mathrm{M}^{-1} \mathrm{~s}^{-1} \\
2 \mathrm{SO}_{5}{ }^{\bullet-} \rightarrow \mathrm{S}_{2} \mathrm{O}_{8}{ }^{2-}+\mathrm{O}_{2} 2.2 \times 10^{8} \mathrm{M}^{-1} \mathrm{~s}^{-1} \\
\mathrm{O}_{3}{ }^{\bullet-} \rightleftharpoons \mathrm{O}^{\bullet-}+\mathrm{O}_{2} 2.1 \times 10^{3} \mathrm{M}^{-1} \mathrm{~s}^{-1} \\
\mathrm{O}^{\bullet-}+\mathrm{H}_{2} \mathrm{O} \rightarrow{ }^{\bullet} \mathrm{OH}+\mathrm{OH}^{-} 10^{8} \mathrm{~s}^{-1}
\end{gathered}
$$

In addition, some studies reported that both $\mathrm{HSO}_{5}{ }^{-}$and $\mathrm{SO}_{5}{ }^{2-}$ could also react with $\mathrm{H}_{2} \mathrm{O}$ to produce $\mathrm{H}_{2} \mathrm{O}_{2}$, thus enhancing ${ }^{\bullet} \mathrm{OH}$ generation during the $\mathrm{O}_{3} / \mathrm{PMS}$ system (Equations (18)-(20)). Moreover, $\mathrm{SO}_{4}{ }^{\bullet-}$ could react with $\mathrm{H}_{2} \mathrm{O}$ or $\mathrm{OH}^{-}$to produce ${ }^{\bullet} \mathrm{OH}$ according to Equations (21) and (22) [13,15,59]. On the other hand, ${ }^{1} \mathrm{O}_{2}$ and $\mathrm{O}_{2}{ }^{\bullet-}$ would be produced in ozonation system. The self-decomposition of PMS would also produce ${ }^{1} \mathrm{O}_{2}$ according to Equation (23) [14].

$$
\begin{gathered}
\mathrm{HSO}_{5}{ }^{-}+\mathrm{H}_{2} \mathrm{O} \rightarrow \mathrm{H}_{2} \mathrm{O}_{2}+\mathrm{HSO}_{4}{ }^{-} \\
\mathrm{SO}_{5}{ }^{2-}+\mathrm{H}_{2} \mathrm{O} \rightarrow \mathrm{H}_{2} \mathrm{O}_{2}+\mathrm{SO}_{4}{ }^{2-}
\end{gathered}
$$




$$
\begin{gathered}
2 \mathrm{O}_{3}+\mathrm{H}_{2} \mathrm{O}_{2} \rightarrow 2^{\bullet} \mathrm{OH}+3 \mathrm{O}_{2} \\
\mathrm{SO}_{4}{ }^{\bullet-}+\mathrm{OH}^{-} \rightarrow \mathrm{SO}_{4}{ }^{2-}+{ }^{\bullet} \mathrm{OH} \quad(6.5 \pm 1.0) \times 10^{7} \mathrm{M}^{-1} \mathrm{~s}^{-1} \\
\mathrm{SO}_{4}{ }^{\bullet-}+\mathrm{H}_{2} \mathrm{O} \rightarrow \mathrm{H}^{+}+\mathrm{SO}_{4}{ }^{-}+{ }^{\bullet} \mathrm{OH} \quad<3 \times 10^{3} \mathrm{~s}^{-1} \\
\mathrm{SO}_{5}{ }^{2-}+\mathrm{HSO}_{5}{ }^{-} \rightarrow \mathrm{HSO}_{4}{ }^{-}+\mathrm{SO}_{4}{ }^{2-}+{ }^{1} \mathrm{O}_{2}
\end{gathered}
$$

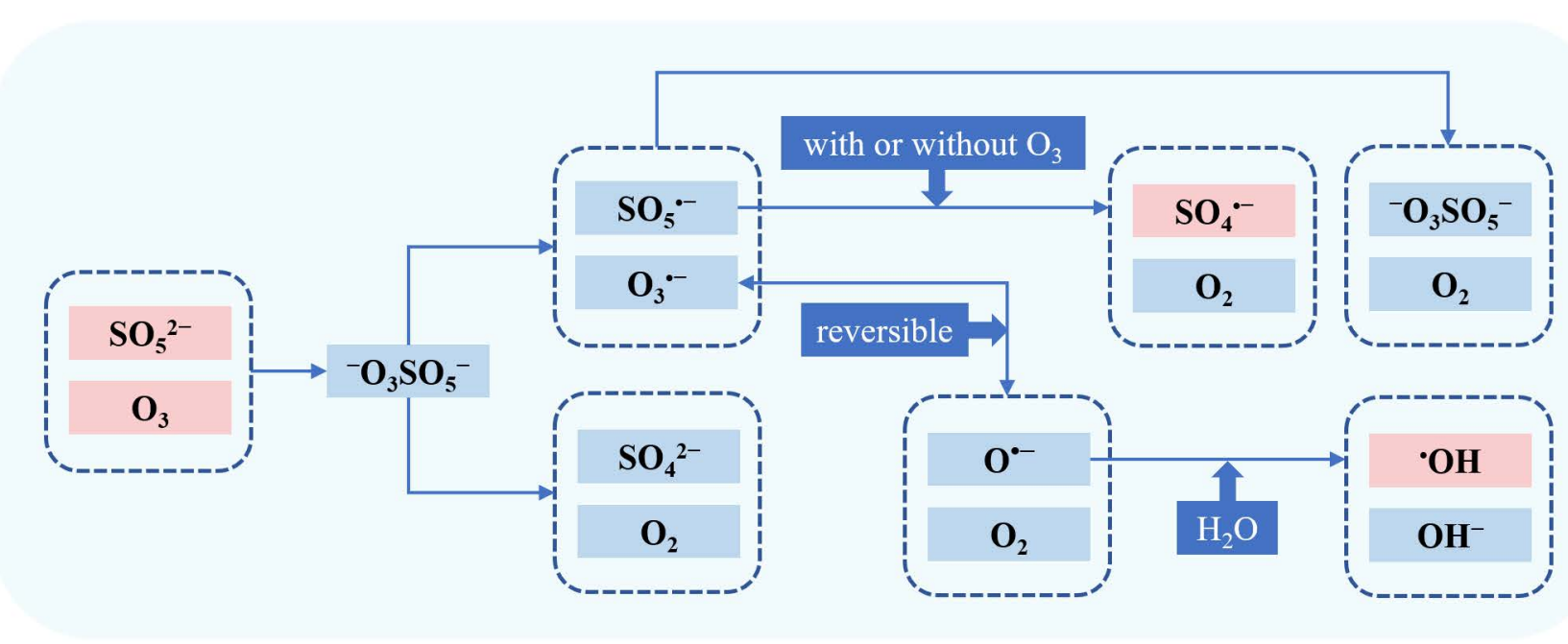

Figure 2. The mechanism of the simultaneous production of ${ }^{\bullet} \mathrm{OH}$ and $\mathrm{SO}_{4}{ }^{\bullet-}$ in the $\mathrm{O}_{3} / \mathrm{PMS}$ system.

\subsubsection{Influencing Factors}

The influence of reaction conditions on the $\mathrm{O}_{3} / \mathrm{PMS}$ system is shown in Table 1. Related research mainly focuses on the influence of $\mathrm{pH}$, concentration and molar ratio of $\mathrm{O}_{3}$ and PMS, temperature, inorganic ions, and NOM on the $\mathrm{O}_{3} / \mathrm{PMS}$ system. These studies have explored the internal mechanism by analyzing the impact of the changes in external conditions on the $\mathrm{O}_{3} / \mathrm{PMS}$ system. These factors mainly influence the $\mathrm{O}_{3} / \mathrm{PMS}$

\begin{tabular}{|c|c|c|}
\hline Influence Factor & Performance & Refs. \\
\hline $\mathrm{pH}$ & 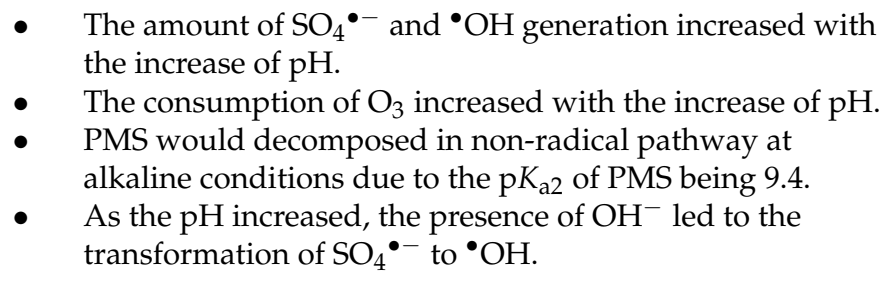 & {$[10,30,59-62]$} \\
\hline $\mathrm{O}_{3}$ dosage & $\begin{array}{l}\text { - The promoting effects on the generation of radicals was } \\
\text { stronger under higher } \mathrm{O}_{3} \text { dosage. } \\
\text { Excessive } \mathrm{O}_{3} \text { dosage could influence the amount of } \\
\text { effective free radicals and acted as scavenger. }\end{array}$ & {$[15,36,63]$} \\
\hline PMS dosage & $\begin{array}{l}\text { - Increased PMS dosage accelerated the } \mathrm{O}_{3} \text { decomposition. } \\
\text { Excessive PMS scavenged the free radicals }\left({ }^{\bullet} \mathrm{OH} \text { and }\right. \\
\left.\mathrm{SO}_{4}^{\bullet-}\right) \text { via unreacted PMS and reducing } \mathrm{pH} \text {. }\end{array}$ & {$[13-15,36,59,64,65]$} \\
\hline
\end{tabular}
system by affecting the decomposition of $\mathrm{O}_{3}$, the activation of PMS, and the generation and conversion of free radicals.

Table 1. The influence of reaction conditions on the $\mathrm{O}_{3} / \mathrm{PMS}$ system. 
Table 1. Cont.

\begin{tabular}{|c|c|c|}
\hline Influence Factor & Performance & Refs. \\
\hline $\mathrm{O}_{3}: \mathrm{PMS}$ & 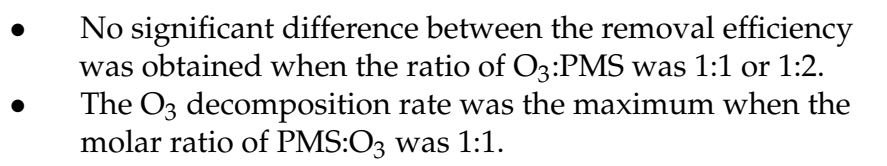 & {$[16,60]$} \\
\hline Temperature & $\begin{array}{l}\text { - } \mathrm{O}_{3} \text { decomposition rate increased with the increase of } \\
\text { temperature. } \\
\text { The O-O bond in PMS was easily broken at high } \\
\text { temperature. } \\
\text { The high reaction temperature could facilitate the } \\
\text { formation of }{ }^{\bullet} \mathrm{OH} \text { and } \mathrm{SO}_{4}{ }^{\bullet-} \text {. } \\
\mathrm{O}_{3} / \mathrm{PMS} \text { system was not thermodynamically controlled in } \\
\text { the } 5-40^{\circ} \mathrm{C} \text { temperature range. }\end{array}$ & {$[14,15,32,34]$} \\
\hline Ionic strength & $\begin{array}{l}\text { Various ionic strength by different buffer concentrations } \\
\text { had no effect on the } \mathrm{O}_{3} / \mathrm{PMS} \text { system. }\end{array}$ & [10] \\
\hline Inorganic ions & $\begin{array}{l}\text { - } \mathrm{HCO}_{3}^{-} \text {and } \mathrm{CO}_{3}^{2-} \text { could react with }{ }^{\bullet} \mathrm{OH} \text { and } \mathrm{SO}_{4}{ }^{\bullet-} \text { to } \\
\text { produce the carbonate radical. } \\
\text { The reaction between } \mathrm{Cl}^{-} \text {and } \mathrm{SO}_{4}^{\bullet-} \text { could cause the } \\
\text { formation of }{ }^{\bullet} \mathrm{OH} \text { and } \mathrm{Cl} \text {-containing radicals. } \\
\mathrm{Cl}^{-} \text {had no significant effect on }{ }^{\bullet} \mathrm{OH} \text {-based AOPs at } \\
\text { neutral pH. } \\
\mathrm{NO}_{2}^{-} \text {and phosphate ions signified a strong inhibition } \\
\text { effect. }\end{array}$ & {$[10,14,15,32,47,64,66-69]$} \\
\hline $\mathrm{NOM}$ & $\begin{array}{l}\text { - } \mathrm{NOM} \text { acted as a promoter and inhibitor for the generation } \\
\text { of }{ }^{\bullet} \mathrm{OH} \text {. } \\
\mathrm{NOM}^{-} \text {was a stronger scavenger for } \\
\mathrm{HCO}_{3}{ }^{-} \mathrm{OH} \text { and } \mathrm{SO}_{4}^{\bullet-} \text { than }\end{array}$ & {$[10,14,15,32,70]$} \\
\hline
\end{tabular}

$\mathrm{pH}$ is an important factor in the $\mathrm{O}_{3} / \mathrm{PMS}$ system because of its remarkable effect on the decomposition of $\mathrm{O}_{3}$, the speciation of PMS, and the conversation of free radicals. In acidic conditions, the presence of excessive proton $\left(\mathrm{H}^{+}\right)$could scavenge ${ }^{\bullet} \mathrm{OH}$ and $\mathrm{SO}_{4}{ }^{\bullet-}$ based on Equations (24) and (25) [31]. As the pH increases up to alkaline, the decomposition of $\mathrm{O}_{3}$ accelerates, resulting in the formation of more ${ }^{\bullet} \mathrm{OH}$ [71]. In addition, since $\mathrm{p} K_{\mathrm{a} 2}$ of PMS is 9.4, the dominant species of PMS would change from $\mathrm{HSO}_{5}{ }^{-}$to $\mathrm{SO}_{5}{ }^{2-}$ under alkaline conditions, which could induce more $\mathrm{SO}_{4}{ }^{\bullet-}$ generation [36,72]. Besides, according to Equations (1), (2), (26), and (27), $\mathrm{O}_{3}$ and PMS could react with $\mathrm{OH}^{-}$to produce $\mathrm{HO}_{2}{ }^{-}$, which then reacts with $\mathrm{O}_{3}$ and $\mathrm{PMS}$ to generate ${ }^{\bullet} \mathrm{OH}$ and $\mathrm{SO}_{4}{ }^{\bullet-}$, respectively $[32,41,73]$. At the same time, the presence of $\mathrm{OH}^{-}$leads to the transformation of $\mathrm{SO}_{4}{ }^{\bullet-}$ to ${ }^{\bullet} \mathrm{OH}$ based on Equation (21) [13,15,30].

$$
\begin{gathered}
\cdot \mathrm{OH}+\mathrm{H}^{+}+\mathrm{e}^{-} \rightarrow \mathrm{H}_{2} \mathrm{O} \\
\mathrm{SO}_{4}{ }^{--}+\mathrm{H}^{+}+\mathrm{e}^{-} \rightarrow \mathrm{HSO}_{4}{ }^{-} \\
\mathrm{HSO}_{5}{ }^{-}+\mathrm{OH}^{-} \rightarrow \mathrm{HO}_{2}{ }^{-}+\mathrm{SO}_{4}{ }^{2-}+\mathrm{H}^{+} \\
\mathrm{HSO}_{5}{ }^{-}+\mathrm{HO}_{2}{ }^{-} \rightarrow \mathrm{SO}_{4}{ }^{\bullet-}+\mathrm{O}_{2}{ }^{\bullet-}+\mathrm{H}_{2} \mathrm{O} \quad(6.5 \pm 1.0) \times 10^{7} \mathrm{M}^{-1} \mathrm{~s}^{-1}
\end{gathered}
$$

The dosage and the molar ratio of $\mathrm{O}_{3}$ and PMS are also very important influencing factors in the $\mathrm{O}_{3} / \mathrm{PMS}$ system. The increase of $\mathrm{O}_{3}$ and PMS dosage leads to the generation of more free radicals in a proper range [10,36], while self-consumption between free radicals also occurs when there are too many ${ }^{\bullet} \mathrm{OH}$ and $\mathrm{SO}_{4}{ }^{\bullet-}$ in the solution, according to Equations (28)-(30) $[13,15,47,51,74]$. On the other hand, excessive $\mathrm{O}_{3}$ and PMS would exhibit an inhibitory effect on the reaction. Specifically, excessive $\mathrm{O}_{3}$ could influence the amount of free radicals and act as scavenger based on Equations (31) and (32) [32,63,75]. Excessive PMS could act as a scavenger of ${ }^{\circ} \mathrm{OH}$ and $\mathrm{SO}_{4}{ }^{\bullet-}$ and facilitate the transformation of abundant $\mathrm{SO}_{4}{ }^{--}$into $\mathrm{SO}_{4}{ }^{2-}$, as described in Equations (33) and (34) [10,13-15,36,72]. 
In addition, the high concentration of PMS would reduce the $\mathrm{pH}$ value and excessive $\mathrm{H}^{+}$ could scavenge free radicals [31,32]. When the molar ratio of PMS: $\mathrm{O}_{3}$ was 1:1, the amount of PMS that could be activated by $\mathrm{O}_{3}$ tended to stabilize [60]. By contrast, $\mathrm{H}_{2} \mathrm{O}_{2}: \mathrm{O}_{3}=0.5$ was the optimal molar ratio for the $\mathrm{O}_{3} / \mathrm{H}_{2} \mathrm{O}_{2}$ system [76,77].

$$
\begin{aligned}
& \mathrm{SO}_{4}{ }^{\bullet-}+\mathrm{SO}_{4}{ }^{\bullet-} \rightarrow \mathrm{S}_{2} \mathrm{O}_{8}{ }^{2-} \quad 7.0 \times 10^{8} \mathrm{M}^{-1} \mathrm{~s}^{-1} \\
& \bullet \mathrm{OH}+{ }^{\bullet} \mathrm{OH} \rightarrow \mathrm{H}_{2} \mathrm{O}_{2} \\
& \mathrm{SO}_{4}{ }^{\bullet-}+{ }^{\bullet} \mathrm{OH} \rightarrow \mathrm{HSO}_{5}{ }^{-} \\
& \mathrm{O}_{3}+\bullet \mathrm{OH} \rightarrow \mathrm{HO}_{2} \bullet+\mathrm{O}_{2} \quad 1.0 \times 10^{8} \mathrm{M}^{-1} \mathrm{~s}^{-1} \\
& \mathrm{O}_{3}+\mathrm{SO}_{4}{ }^{\bullet-} \rightarrow \mathrm{SO}_{5} \cdot{ }^{\bullet-}+\mathrm{O}_{2} \\
& \mathrm{HSO}_{5}{ }^{-}+{ }^{\bullet} \mathrm{OH} \rightarrow \mathrm{SO}_{5}{ }^{--}+\mathrm{H}_{2} \mathrm{O} \quad 5.0 \times 10^{6} \mathrm{M}^{-1} \mathrm{~s}^{-1} \\
& \mathrm{HSO}_{5}{ }^{-}+\mathrm{SO}_{4}{ }^{\bullet-} \rightarrow \mathrm{SO}_{5}{ }^{\bullet-}+\mathrm{HSO}_{4}{ }^{-} \quad 1.0 \times 10^{6} \mathrm{M}^{-1} \mathrm{~s}^{-1}
\end{aligned}
$$

Temperature is a very important influencing factor in all reaction systems. Although the study by Shao et al. indicated that the $\mathrm{O}_{3} /$ PMS system was not controlled by thermodynamics in the temperature range of $5-40{ }^{\circ} \mathrm{C}$ [32], other studies have shown that the amount of free radicals in the $\mathrm{O}_{3} /$ PMS system increased with the increase of temperature $[33,78,79]$. Specifically, the O-O bond of PMS was easily broken at a higher temperature while PMS activation was reduced at a lower temperature, leading to the reduction of $\mathrm{SO}_{4}{ }^{\bullet-}$. Furthermore, the solubility and availability of $\mathrm{O}_{3}$ to produce free radicals in aqueous solution were reduced at a higher temperature [80-82].

The presence of some kinds of inorganic ions has a significant impact on the $\mathrm{O}_{3} / \mathrm{PMS}$ system [14], while the impact of different ionic strengths on the $\mathrm{O}_{3} / \mathrm{PMS}$ system is very limited. According to Equations (35)-(37), $\mathrm{Cl}^{-}$had limited effect on ${ }^{\bullet} \mathrm{OH}$ because the reaction between $\mathrm{Cl}^{-}$and ${ }^{\bullet} \mathrm{OH}$ was reversible and the generation of $\mathrm{Cl}^{\bullet}$ occurred only at low $\mathrm{pH}$ conditions [21]. On the other hand, $\mathrm{Cl}^{-}$could scavenge $\mathrm{SO}_{4}{ }^{\bullet-}$ to produce less reactive $\mathrm{Cl}^{\bullet}$ (Equations (38) and (39)) $[32,37,38]$. The reaction between $\mathrm{Cl}^{-}$and $\mathrm{SO}_{4}{ }^{\bullet-}$ could lead to the generation of ${ }^{\bullet} \mathrm{OH}[40,83] . \mathrm{Br}^{-}$affected the $\mathrm{O}_{3} / \mathrm{PMS}$ system through rapid and irreversible reacting with ${ }^{\bullet} \mathrm{OH}$ and $\mathrm{SO}_{4}{ }^{\bullet-}$ (Equations (40) and (41)) $[84,85]$. Equations (42)-(45) describe the reaction of free radicals with $\mathrm{CO}_{3}{ }^{2-}$ and $\mathrm{HCO}_{3}{ }^{-}$[32]. $\mathrm{CO}_{3}{ }^{2-}$ and $\mathrm{HCO}_{3}{ }^{-}$could quench the free radicals effectively to generate $\mathrm{CO}_{3}{ }^{\circ-}$, with lower redox potential $\left(E_{0}=1.78 \mathrm{~V}\right)$ than ${ }^{\bullet} \mathrm{OH}$ and $\mathrm{SO}_{4}{ }^{--}$[14]. $\mathrm{NO}_{2}{ }^{-}$influenced oxidants and free radicals due to its reducibility (Equations $(46)$ and $(47))[14,86]$. Phosphate ions showed a strong inhibitory effect on $\mathrm{O}_{3}$ decomposition [87]. Therefore, the use of phosphate buffer solution in the $\mathrm{O}_{3} / \mathrm{PMS}$ system should control the concentration of phosphate ions.

$$
\begin{aligned}
& \bullet \mathrm{OH}+\mathrm{Cl}^{-} \rightarrow \mathrm{ClOH}^{\bullet-} \quad 4.3 \times 10^{9} \mathrm{M}^{-1} \mathrm{~s}^{-1} \\
& \mathrm{ClOH}^{\bullet-} \rightarrow{ }^{\bullet} \mathrm{OH}+\mathrm{Cl}^{-} \quad 6.1 \times 10^{9} \mathrm{M}^{-1} \mathrm{~s}^{-1} \\
& \mathrm{ClOH}^{\bullet-}+\mathrm{H}^{+} \rightarrow \mathrm{H}_{2} \mathrm{O}+\mathrm{Cl}^{\bullet} \quad 2.1 \times 10^{10} \mathrm{M}^{-1} \mathrm{~s}^{-1} \\
& \mathrm{SO}_{4}{ }^{\bullet-}+\mathrm{Cl}^{-} \rightarrow \mathrm{SO}_{4}{ }^{2-}+\mathrm{Cl}^{\bullet} \quad 3.0 \times 10^{8} \mathrm{M}^{-1} \mathrm{~s}^{-1} \\
& \mathrm{SO}_{4}{ }^{2-}+\mathrm{Cl}^{\bullet} \rightarrow \mathrm{SO}_{4}{ }^{\bullet-}+\mathrm{Cl}^{-} \quad 2.5 \times 10^{8} \mathrm{M}^{-1} \mathrm{~s}^{-1} \\
& \cdot \mathrm{OH}+\mathrm{Br}^{-} \rightarrow \mathrm{BrOH}^{\bullet-} \quad 1.1 \times 10^{10} \mathrm{M}^{-1} \mathrm{~s}^{-1} \\
& \mathrm{SO}_{4}{ }^{\bullet-}+\mathrm{Br}^{-} \rightarrow \mathrm{SO}_{4}{ }^{2-}+\mathrm{Br}^{\bullet} \quad 3.5 \times 10^{9} \mathrm{M}^{-1} \mathrm{~s}^{-1} \\
& \cdot \mathrm{OH}+\mathrm{CO}_{3}{ }^{2-} \rightarrow \mathrm{CO}_{3}{ }^{\bullet-}+\mathrm{OH}^{-} \quad 3.9 \times 10^{8} \mathrm{M}^{-1} \mathrm{~s}^{-1} \\
& \cdot \mathrm{OH}+\mathrm{HCO}_{3}{ }^{-} \rightarrow \mathrm{CO}_{3}{ }^{\bullet-}+\mathrm{H}_{2} \mathrm{O} \quad 8.6 \times 10^{6} \mathrm{M}^{-1} \mathrm{~s}^{-1} \\
& \mathrm{SO}_{4}{ }^{\bullet-}+\mathrm{CO}_{3}{ }^{2-} \rightarrow \mathrm{CO}_{3}{ }^{\bullet-}+\mathrm{SO}_{4}{ }^{2-} \quad 6.1 \times 10^{6} \mathrm{M}^{-1} \mathrm{~s}^{-1} \\
& \mathrm{SO}_{4}{ }^{\bullet-}+\mathrm{HCO}_{3}{ }^{-} \rightarrow \mathrm{CO}_{3}{ }^{\bullet-}+\mathrm{HSO}_{4}{ }^{-} \quad 2.8 \times 10^{6} \mathrm{M}^{-1} \mathrm{~s}^{-1}
\end{aligned}
$$




$$
\begin{gathered}
\mathrm{NO}_{2}{ }^{-}+{ }^{\bullet} \mathrm{OH} \text { or } \mathrm{SO}_{4}{ }^{\bullet-} \rightarrow \mathrm{NO}_{2}{ }^{\bullet}+\mathrm{HO}^{-} \text {or } \mathrm{SO}_{4}{ }^{2-} \\
\mathrm{NO}_{2}{ }^{-}+\mathrm{HSO}_{5}{ }^{-} \text {or } \mathrm{O}_{3} \rightarrow \mathrm{NO}_{3}{ }^{-}+\mathrm{HSO}_{4}{ }^{-} \text {or } \mathrm{O}_{2}
\end{gathered}
$$

NOM plays a dual role in the $\mathrm{O}_{3} /$ PMS system [41,42]. The low concentration of NOM enhanced the decomposition of $\mathrm{O}_{3}$ to produce ${ }^{\bullet} \mathrm{OH}$ [43]. However, $\mathrm{NOM}$ acted as a scavenger for ${ }^{\bullet} \mathrm{OH}$ and $\mathrm{SO}_{4}{ }^{\bullet-}$ at relatively high concentrations [70]. HA, as an important component of NOM, also played an obvious dual role in the $\mathrm{O}_{3} / \mathrm{PMS}$ system [15].

\section{Degradation of Micropollutants Using the $\mathrm{O}_{3} /$ PMS System}

\subsection{Degradation Effect and Energy Efficiency}

The $\mathrm{O}_{3} / \mathrm{PMS}$ system can quickly and effectively generate ${ }^{\bullet} \mathrm{OH}$ and $\mathrm{SO}_{4}{ }^{\bullet-}$, so it is widely used in the research of micropollutant degradation. As shown in Table 2, the $\mathrm{O}_{3} /$ PMS system exhibits a good degradation effect when treating sewage-containing general chemicals, agricultural chemicals, and medical chemicals. The $\mathrm{SO}_{4}{ }^{\bullet-}$ formed by PMS activation exists in the system for a long time, so it can oxidize micropollutants more effectively. Specifically, the $\mathrm{O}_{3} / \mathrm{PMS}$ system has high efficiency in degrading typical micropollutants in agricultural and medical industries, so it can be used for soil remediation and medical wastewater treatment. There are many factors that affect the degradation effect of $\mathrm{O}_{3} / \mathrm{PMS}$ on micropollutants, such as the type and concentration of micropollutants, the concentration and molar ratio of $\mathrm{O}_{3}$ and $\mathrm{PMS}, \mathrm{pH}$, and temperature. Tang et al. studied the effect of the $\mathrm{O}_{3} / \mathrm{PMS}$ system on the degradation of micropollutants with different molecular weights (MW). The MW distributions were divided into five fractions: F1 $(<3 \mathrm{kDa}), \mathrm{F} 2$

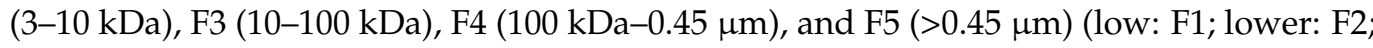
higher: F3, F4; high: F5). The results indicated that $\mathrm{O}_{3} / \mathrm{PMS}$ oxidation degraded higher MW fractions more efficiently than low MW fractions in DOM [88].

The reaction rate constants between different micropollutants with $\mathrm{O}_{3}$ and free radicals are shown in Table 3. The reaction rate constants determine which ROS plays a key role in the degradation of target micropollutants in the $\mathrm{O}_{3} / \mathrm{PMS}$ system. For example, when the solution $\mathrm{pH}$ shifted from neutral to alkaline, the proportion of $\mathrm{O}_{3}$ that directly reacted with ACE decreased, resulting in an enhanced formation of $\mathrm{SO}_{4}{ }^{\bullet-}$ and suppressed formation of ${ }^{\bullet} \mathrm{OH}$. Considering that $\mathrm{SO}_{4}{ }^{\bullet-}$ degraded ACE more slowly than ${ }^{\bullet} \mathrm{OH}$ did, the oxidation capacity of the system was weakened due to the decrease of ${ }^{\bullet} \mathrm{OH}$ formation [32]. On the other hand, the synergy between the various $\mathrm{ROS}$ (i.e., $\mathrm{O}_{3},{ }^{\bullet} \mathrm{OH}, \mathrm{SO}_{4}{ }^{\bullet-}, \mathrm{O}_{2}{ }^{\bullet-},{ }^{1} \mathrm{O}_{2}$ ) produced by the $\mathrm{O}_{3} /$ PMS system results in the degradation efficiency of micropollutants faster than other $\mathrm{O}_{3}$-based oxidation processes (i.e., $\mathrm{O}_{3}, \mathrm{O}_{3} / \mathrm{H}_{2} \mathrm{O}_{2}, \mathrm{O}_{3} /$ PDS). Wen et al. reported that the degradation efficiency of $p$ CBA by $\mathrm{O}_{3}$ alone and $\mathrm{O}_{3} / \mathrm{H}_{2} \mathrm{O}_{2}$ was only $48.9 \%$ and $54.7 \%$ after $5 \mathrm{~min}$, respectively. On the contrary, $p \mathrm{CBA}$ was fully degraded by $\mathrm{O}_{3} / \mathrm{PMS}$ in less than $5 \mathrm{~min}$ [16]. In the study by Yang et al., it was found that the removal rate of ATZ by $\mathrm{O}_{3} / \mathrm{PMS}$ reached $81 \%$ in $10 \mathrm{~min}$, while the removal rate of $\mathrm{O}_{3}$ alone in 20 min was only $27 \%$ [10]. Besides, the removal rate of PMT within $10 \mathrm{~min}$ in the $\mathrm{O}_{3} / \mathrm{PMS}$ system was about $99.27 \%$, while the removal rate of $\mathrm{PMT}$ by $\mathrm{O}_{3}$ alone and $\mathrm{O}_{3} / \mathrm{PDS}$ was $46.16 \%$ and $53.45 \%$, respectively [15].

Yu et al. studied the electrical energy per order (EE/O) of ATL in several AOPs. Specifically, the $\mathrm{EE} / \mathrm{O}$ of $\mathrm{UV} / \mathrm{O}_{3} / \mathrm{PMS}, \mathrm{UV} / \mathrm{O}_{3}, \mathrm{O}_{3} / \mathrm{PMS}$, UV/PMS and $\mathrm{O}_{3}$ was $4.48 \times 10^{-4}$, $2.37 \times 10^{-4}, 5.37 \times 10^{-4}, 4.40 \times 10^{-4}$, and $2.80 \times 10^{-4} \mathrm{~kW} \cdot \mathrm{h} / \mathrm{L}$, respectively, which followed the order: $\mathrm{O}_{3} / \mathrm{PMS}>\mathrm{UV} / \mathrm{O}_{3} / \mathrm{PMS} \approx \mathrm{UV} / \mathrm{PMS}>\mathrm{O}_{3}>\mathrm{UV} / \mathrm{O}_{3}$. The results indicated that the $\mathrm{O}_{3} / \mathrm{PMS}$ system was the most energy-intensive process for ATL degradation [89]. Besides, Miklos et al. also reported the higher energy efficiency for the $\mathrm{SO}_{4}{ }^{\bullet-}$-based AOPs [90]. This is mainly due to the selectivity of $\mathrm{SO}_{4}{ }^{\bullet-}$, which will consume more energy when degrading the target micropollutants at a low reaction rate with $\mathrm{SO}_{4}{ }^{\bullet-}$. 
Table 2. Degradation effect of $\mathrm{O}_{3} /$ PMS process on micropollutants.

\begin{tabular}{|c|c|c|c|c|c|}
\hline Type & Object & Reaction Conditions & Performance & Oxidizing Agent & Ref. \\
\hline \multirow{6}{*}{ General chemicals } & $p$ CBA & $\begin{array}{l}\text { - } \quad p C B A=5 \mu \mathrm{M}, \mathrm{O}_{3}=5 \mathrm{mg} / \mathrm{L} \\
\mathrm{PMS}_{3} \mathrm{O}_{3}(\text { molar ratio) }=1: 1 \\
\mathrm{pH}=7.5\end{array}$ & $\begin{array}{l}-\quad>90 \% \\
\text { removed in } 1 \\
\min \end{array}$ & $\mathrm{O}_{3},{ }^{\bullet} \mathrm{OH}, \mathrm{SO}_{4}^{\bullet-}$ & {$[60]$} \\
\hline & & $\begin{array}{l}\text { - } \quad p \mathrm{CBA}=9 \mu \mathrm{M}, \mathrm{O}_{3}=0.103 \\
\mathrm{mM}, \mathrm{PMS}: \mathrm{O}_{3} \\
(\mathrm{molar} \text { ratio) }=1: 1, \mathrm{pH}=6.0 \\
\mathrm{T}=20^{\circ} \mathrm{C}\end{array}$ & 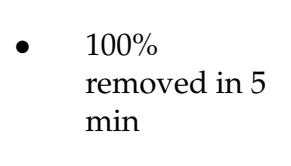 & ${ }^{\bullet} \mathrm{OH}, \mathrm{SO}_{4}^{\bullet-}$ & [16] \\
\hline & 4-nitrophenol & $\begin{array}{l}\text { 4-nitrophenol }=50 \mathrm{mg} / \mathrm{L}, \mathrm{O}_{3} \\
=30 \mathrm{mg} / \mathrm{L}, \mathrm{PMS}=100 \\
\mathrm{mg} / \mathrm{L}, \mathrm{T}=25^{\circ} \mathrm{C}, \text { catalyst } \\
\text { loading }\left(\mathrm{MnO}_{2} / \mathrm{rGO}\right)= \\
0.1 \mathrm{~g} / \mathrm{L}\end{array}$ & $\begin{array}{l}\text { - } \quad 100 \% \\
\text { removed in } \\
45 \mathrm{~min}\end{array}$ & $\bullet \mathrm{OH}, \mathrm{SO}_{4}^{\bullet-}$ & [91] \\
\hline & $\mathrm{CN}$ & $\begin{array}{l}\text { - } \mathrm{CN}=50 \mathrm{mg} / \mathrm{L}, \mathrm{O}_{3}=0.4 \mathrm{~g} / \mathrm{h}, \\
\mathrm{PMS}=100 \mathrm{mg} / \mathrm{L}, \mathrm{pH}=10.0 \\
\mathrm{~T}=25^{\circ} \mathrm{C}\end{array}$ & $\begin{array}{l}\text { - } 100 \% \\
\text { removed in } \\
10 \mathrm{~min}\end{array}$ & ${ }^{\bullet} \mathrm{OH}, \mathrm{SO}_{4}^{\bullet-}$ & [34] \\
\hline & $\mathrm{OA}$ & $\begin{array}{l}\text { - } \mathrm{OA}=15 \mu \mathrm{M}, \mathrm{O}_{3}=1.135 \\
\mathrm{mg} / \mathrm{min}, \mathrm{PMS}=100 \mu \mathrm{M}, \mathrm{pH} \\
=7.0, \mathrm{~T}=20 \pm 2{ }^{\circ} \mathrm{C},(\mathrm{GO}= \\
10 \mathrm{mg} / \mathrm{L})\end{array}$ & $\begin{array}{l}\text { - } 67 \% \text { removed } \\
\text { in } 25 \mathrm{~min} ; \\
(74 \% \\
\text { removed in } \\
25 \mathrm{~min})\end{array}$ & & [92] \\
\hline & BTA & 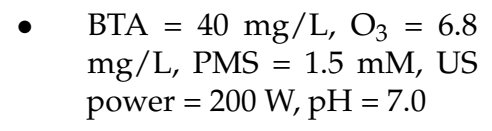 & $\begin{array}{l}100 \% \text { re- } \\
\text { moved in } 60 \\
\text { min }\end{array}$ & $\bullet \mathrm{OH}$ & [30] \\
\hline \multirow{5}{*}{$\begin{array}{l}\text { Agricultural } \\
\text { chemicals }\end{array}$} & $\mathrm{ACE}$ & $\begin{array}{l}\text { - } \mathrm{ACE}=8.0 \mathrm{mg} / \mathrm{L}, \mathrm{O}_{3}=60 \pm \\
5 \mu \mathrm{g} / \mathrm{min}, \mathrm{PMS}=0.4 \mu \mathrm{M} \\
\mathrm{pH}=7.4, \mathrm{~T}=15 \pm 1^{\circ} \mathrm{C}\end{array}$ & $\begin{array}{l}->90 \% \\
\text { removed in } \\
15 \mathrm{~min}\end{array}$ & $\mathrm{O}_{3},{ }^{\bullet} \mathrm{OH}, \mathrm{SO}_{4}^{\bullet-}$ & [32] \\
\hline & ATZ & $\begin{array}{l}\text { - } \quad \mathrm{ATZ}=5 \mu \mathrm{M}, \mathrm{O}_{3}=5 \mathrm{mg} / \mathrm{L} \\
\mathrm{PMS}: \mathrm{O}_{3} \text { (molar ratio) }=1: 1 \\
\mathrm{pH}=7.5\end{array}$ & $\begin{array}{l}-\quad>90 \% \\
\text { removed in } \\
1 \mathrm{~min}\end{array}$ & $\mathrm{O}_{3},{ }^{\bullet} \mathrm{OH}, \mathrm{SO}_{4}^{\bullet-}$ & {$[60]$} \\
\hline & & $\begin{array}{l}\mathrm{ATZ}=1 \mu \mathrm{M}, \mathrm{O}_{3}=1 \mathrm{mg} / \mathrm{L} \\
\mathrm{PMS}=10 \mu \mathrm{M}, \mathrm{pH}=8, \mathrm{~T}=15 \\
\pm 1^{\circ} \mathrm{C}\end{array}$ & $\begin{array}{l}\text { - } \quad 81 \% \text { removad } \\
\text { in } 10 \mathrm{~min}\end{array}$ & ${ }^{\bullet} \mathrm{OH}, \mathrm{SO}_{4}^{\bullet-}$ & [10] \\
\hline & PMT & $\begin{array}{l}\text { - } \quad \mathrm{PMT}=2 \mathrm{mg} / \mathrm{L}, \mathrm{O}_{3}=7.5 \\
\mathrm{mg} / \mathrm{min}, \mathrm{PMS}=100 \mathrm{mg} / \mathrm{L} \\
\mathrm{pH}=6.5, \mathrm{~T}=20^{\circ} \mathrm{C}\end{array}$ & $\begin{array}{l}>99.27 \% \\
\text { removed in } \\
10 \mathrm{~min}\end{array}$ & $\bullet \mathrm{OH}, \mathrm{SO}_{4}{ }^{\bullet-}$ & [15] \\
\hline & $2,4-\mathrm{D}$ & $\begin{array}{l}\text { - } 2,4-\mathrm{D}=200 \mathrm{mg} / \mathrm{L}, \mathrm{O}_{3}=16 \\
\mathrm{mg} / \mathrm{L}, \mathrm{PMS}=2.0 \mathrm{mM}, \mathrm{pH}= \\
\text { 6.0, catalyst dosage }(\mathrm{MCFNs}) \\
=0.2 \mathrm{~g} / \mathrm{L}\end{array}$ & $\begin{array}{ll}100 \% & \text { re- } \\
\text { moved } & \text { in } \\
40 \mathrm{~min} & \end{array}$ & $\begin{array}{c}\bullet \mathrm{OH}, \mathrm{SO}_{4}{ }^{\bullet-}, \mathrm{O}_{2}{ }^{\bullet-}, \\
{ }^{1} \mathrm{O}_{2}\end{array}$ & [14] \\
\hline \multirow{2}{*}{ Medical chemicals } & KET & $\begin{array}{l}\mathrm{KET}=5 \mu \mathrm{M}, \mathrm{O}_{3}=5 \mathrm{mg} / \mathrm{L} \\
\mathrm{PMS}: \mathrm{O}_{3}(\text { molar ratio })=1: 1 \\
\mathrm{pH}=7.5\end{array}$ & $\begin{array}{l}>90 \% \\
\text { removed in } \\
1 \mathrm{~min}\end{array}$ & $\mathrm{O}_{3},{ }^{\bullet} \mathrm{OH}, \mathrm{SO}_{4}^{\bullet-}$ & {$[60]$} \\
\hline & METR & $\begin{array}{l}\text { - } \mathrm{METR}=5 \mu \mathrm{M}, \mathrm{O}_{3}=5 \mathrm{mg} / \mathrm{L}, \\
\mathrm{PMS}: \mathrm{O}_{3}(\text { molar ratio) }=1: 1 \\
\mathrm{pH}=7.5\end{array}$ & $\begin{array}{l}-\quad>90 \% \\
\text { removed in } \\
1 \mathrm{~min}\end{array}$ & $\mathrm{O}_{3}, \mathrm{SO}_{4}^{\bullet-}$ & {$[60]$} \\
\hline
\end{tabular}


Table 2. Cont.

\begin{tabular}{|c|c|c|c|c|c|}
\hline Type & Object & Reaction Conditions & Performance & Oxidizing Agent & Ref. \\
\hline & SMT & $\begin{array}{l}-\mathrm{SMT}=10 \mathrm{mg} / \mathrm{L}, \mathrm{O}_{3}=100 \\
\mathrm{mg} / \mathrm{h}, \mathrm{PMS}=0.4 \mathrm{~g} / \mathrm{L}, \mathrm{T}=25 \\
{ }^{\circ} \mathrm{C}, \text { catalyst dosage } \\
(\mathrm{Co}-\mathrm{Ce} / \mathrm{MCM}-48)=0.2 \mathrm{~g} / \mathrm{L}\end{array}$ & $\begin{array}{l}67.2 \% \\
\text { mineralized } \\
\text { at } 90 \mathrm{~min}\end{array}$ & $\cdot \stackrel{\mathrm{OH}, \mathrm{SO}_{4}{ }^{\bullet-} \mathrm{O}_{2}}{{ }^{-} \mathrm{O}_{2}}{ }^{\bullet-}$, & [13] \\
\hline & IPM & $\begin{array}{l}\text { - } \mathrm{IPM}=1 \mu \mathrm{M}, \mathrm{O}_{3}=41.7 \mu \mathrm{M} \\
\mathrm{PMS}=10 \mu \mathrm{M}, \mathrm{pH}=7.0, \mathrm{~T}= \\
25 \pm 1{ }^{\circ} \mathrm{C}\end{array}$ & 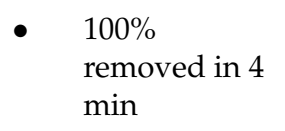 & $\cdot \mathrm{OH}, \mathrm{SO}_{4}^{\bullet-}$ & [59] \\
\hline & IBP & $\begin{array}{l}\text { - } \quad \mathrm{IBP}=5 \mu \mathrm{M}, \mathrm{O}_{3}=31.3 \mu \mathrm{M}, \\
\mathrm{PMS}=6.5 \mu \mathrm{M}, \text { Intial } \mathrm{pH}= \\
7.0, \mathrm{~T}=20^{\circ} \mathrm{C}\end{array}$ & $\begin{array}{l}\text { - } \quad 72 \% \text { removed } \\
\text { in } 20 \mathrm{~min}\end{array}$ & ${ }^{\bullet} \mathrm{OH}, \mathrm{SO}_{4}^{\bullet-}$ & [36] \\
\hline & RBV & $\begin{array}{l}\text { - } \quad \mathrm{RBV}=10 \mu \mathrm{M}, \mathrm{O}_{3}=0.025 \\
\mu \mathrm{M}, \mathrm{PMS}=0.025 \mu \mathrm{M}, \mathrm{pH}= \\
7.0\end{array}$ & $\begin{array}{l}\text { - } \quad 50 \% \text { removed } \\
\text { in } 5 \mathrm{~min}\end{array}$ & $\mathrm{O}_{3},{ }^{\bullet} \mathrm{OH}, \mathrm{SO}_{4}^{\bullet-}$ & [65] \\
\hline & ATL & $\begin{array}{l}\text { - } \mathrm{ATL}=10 \mathrm{mg} / \mathrm{L}, \mathrm{O}_{3}=2.6 \\
\mathrm{mg} / \mathrm{min}, \mathrm{PMS}=66.4 \mathrm{mg} / \mathrm{L} \\
\mathrm{UV} \text { (unknown), } \mathrm{pH}=6.0\end{array}$ & $\begin{array}{l}97.36 \% \\
\text { removed in } 7 \\
\min \end{array}$ & $\bullet \mathrm{OH}, \mathrm{SO}_{4}^{\bullet-}$ & [89] \\
\hline & ASA & 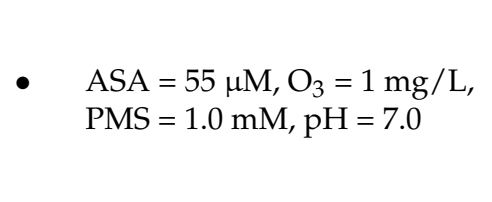 & $\begin{array}{l}\text { The pseudo- } \\
\text { first-order } \\
\text { rate constants } \\
\text { was } 6.01 \times \\
10^{-2} \mathrm{~min}^{-1}\end{array}$ & $\mathrm{O}_{3},{ }^{\bullet} \mathrm{OH}, \mathrm{SO}_{4}^{\bullet-}$ & [93] \\
\hline & PNT & $\begin{array}{l}\text { - } \quad \begin{array}{l}\mathrm{PNT} \\
\mathrm{PMS}\end{array}=55 \mu \mathrm{M}, \mathrm{O}_{3}=1 \mathrm{mg} / \mathrm{L}, \mathrm{pH}=7.0\end{array}$ & $\begin{array}{l}\text { The pseudo- } \\
\text { first-order } \\
\text { rate constants } \\
\text { was } 1.77 \times \\
10^{-1} \mathrm{~min}^{-1}\end{array}$ & $\mathrm{O}_{3}, \bullet \mathrm{OH}, \mathrm{SO}_{4}^{\bullet-}$ & [93] \\
\hline & CAP & $\begin{aligned} \text { - } \quad & \mathrm{CAP} \\
\mathrm{PMS} & =5 \mu \mathrm{M}, \mathrm{O}_{3}=2.4 \mathrm{mg} / \mathrm{L}, \mathrm{pH}=7.0\end{aligned}$ & $\begin{array}{l}\text { - } \quad 60 \% \text { removed } \\
\text { in } 30 \mathrm{~min}\end{array}$ & ${ }^{\bullet} \mathrm{OH}, \mathrm{SO}_{4}^{\bullet-}$ & {$[70]$} \\
\hline & SMX & $\begin{array}{l}-\mathrm{SMX}=0.04 \mathrm{mM}, \mathrm{O}_{3}=20 \\
\mathrm{mg} / \mathrm{L}, \mathrm{PMS}=1.2 \mathrm{mM}, \text { Intial } \\
\mathrm{pH}=3.4\left(\mathrm{SNRP}-\mathrm{O}_{3}\right)\end{array}$ & $\begin{array}{l}76.4 \% \\
\text { removed in } \\
30 \mathrm{~min}\end{array}$ & $\mathrm{O}_{3}$ & [94] \\
\hline & BCPMW & $\begin{array}{l}\text { - } \mathrm{COD}=320.0 \mathrm{mg} / \mathrm{L}, \mathrm{TOC}= \\
125 \mathrm{mg} / \mathrm{L}, \mathrm{DOC}=88.0 \\
\mathrm{mg} / \mathrm{L}, \text { color }=118 \text { times, } \mathrm{O}_{3} \\
=50 \mathrm{mg} / \mathrm{L}, \mathrm{PMS}=22.5 \\
\mathrm{mg} / \mathrm{L}, \text { Intial } \mathrm{pH}=7.4-8.9, \mathrm{~T} \\
=16-28^{\circ} \mathrm{C}\end{array}$ & $\begin{array}{l}\text { 60.28\% COD, } \\
44.06 \% \text { TOC, } \\
52.49 \% \text { DOC, } \\
75.26 \% \text { color } \\
\text { removed }\end{array}$ & & [88] \\
\hline
\end{tabular}


Table 3. The reaction rate constant between the substance and $\mathrm{O}_{3},{ }^{\bullet} \mathrm{OH}$ and $\mathrm{SO}_{4}{ }^{\bullet-}$.

\begin{tabular}{|c|c|c|c|c|}
\hline Object & $k_{\mathrm{O} 3}\left(\mathrm{M}^{-1} \mathrm{~s}^{-1}\right)$ & $k_{\mathrm{OH}}\left(\mathrm{M}^{-1} \mathbf{s}^{-1}\right)$ & $k_{\mathrm{SO} 4-}\left(\mathrm{M}^{-1} \mathrm{~s}^{-1}\right)$ & Refs. \\
\hline$p \mathrm{CBA}$ & 0.15 & $5.0 \times 10^{9}$ & $3.6 \times 10^{8}$ & {$[16,95]$} \\
\hline KET & 0.40 & $8.4 \times 10^{9}$ & n.d. & {$[96]$} \\
\hline ATZ & $6.3-16$ & $(2.5-3.0) \times 10^{9}$ & $(2.4-2.6) \times 10^{9}$ & {$[10,93,97]$} \\
\hline METR & 253 & $3.54 \times 10^{9}$ & $2.74 \times 10^{9}$ & {$[98,99]$} \\
\hline METO & $2 \times 10^{3}$ & $6.8 \times 10^{9}$ & $5.11 \times 10^{9}$ & [99-101] \\
\hline VEN & $8.5 \times 10^{3}$ & $8.15 \times 10^{9}$ & $3.53 \times 10^{9}$ & {$[99,102,103]$} \\
\hline CBZ & $3 \times 10^{5}$ & $8.8 \times 10^{9}$ & $1.92 \times 10^{9}$ & [103-105] \\
\hline NB & 0.09 & $(3.9-5.9) \times 10^{9}$ & $<10^{6}$ & {$[10,65,106]$} \\
\hline PMT & 0.76 & $1.9 \times 10^{9}$ & $1.7 \times 10^{9}$ & [15] \\
\hline $\mathrm{MeOH}$ & n.d. & $9.7 \times 10^{8}$ & $2.5 \times 10^{7}$ & {$[47,51]$} \\
\hline $\mathrm{EtOH}$ & n.d. & $(1.2-2.8) \times 10^{8}$ & $(1.6-7.7) \times 10^{7}$ & {$[51,54]$} \\
\hline $\mathrm{AcOH}$ & $3 \times 10^{-5}$ & $1.0 \times 10^{8}$ & $5.0 \times 10^{6}$ & [93] \\
\hline TBA & 0.01 & $(3.8-7.6) \times 10^{8}$ & $(4.0-9.1) \times 10^{5}$ & [54] \\
\hline BA & n.d. & $4.2 \times 10^{9}$ & $1.2 \times 10^{9}$ & {$[107,108]$} \\
\hline IPM & 18 & n.d. & $1.6 \times 10^{9}$ & {$[59,105]$} \\
\hline $\mathrm{ACE}$ & n.d. & $3.8 \times 10^{9}$ & $<2.0 \times 10^{7}$ & [109] \\
\hline IBP & n.d. & $5.23 \times 10^{9}$ & $1.08 \times 10^{9}$ & {$[36,110]$} \\
\hline DEP & n.d. & n.d. & $<10^{6}$ & {$[111,112]$} \\
\hline RBV & 9.8 & $1.9 \times 10^{9}$ & $7.9 \times 10^{7}$ & [65] \\
\hline BTA & $17-23$ & n.d. & n.d. & [92] \\
\hline ASA & 7.32 & $4.18 \times 10^{9}$ & $3.46 \times 10^{8}$ & [93] \\
\hline PNT & 37.3 & $4.99 \times 10^{9}$ & $5.64 \times 10^{8}$ & [93] \\
\hline CAP & 0.291 & $2.27 \times 10^{9}$ & $1.02 \times 10^{8}$ & [70] \\
\hline NOM & n.d. & $3.0 \times 10^{8}$ & $2.35 \times 10^{7}$ & {$[69,113]$} \\
\hline $\mathrm{CO}_{3}{ }^{2-}$ & n.d. & $3.9 \times 10^{8}$ & $6.1 \times 10^{6}$ & [89] \\
\hline $\mathrm{HCO}_{3}{ }^{-}$ & n.d. & $8.5 \times 10^{6}$ & $1.6 \times 10^{6}$ & {$[47,114]$} \\
\hline $\mathrm{NO}_{2}{ }^{-}$ & n.d. & $1.0 \times 10^{10}$ & $8.8 \times 10^{8}$ & {$[47,51]$} \\
\hline
\end{tabular}

n.d.: no data available.

\subsection{Toxicity Changes and Degradation Pathway}

The $\mathrm{O}_{3} / \mathrm{PMS}$ system can significantly reduce the toxicity of micropollutants. Specifically, the biodegradability of activated sludge containing 2,4-D was increased from $8.3 \%$ to $58.9 \%$, and the toxicity was reduced from $76.5 \%$ to $3.8 \%$ after treatment by the PMS/MCFNs $/ \mathrm{O}_{3}$ system [14]. With the oxidation of $\mathrm{O}_{3} / \mathrm{PMS}$, the toxic equivalent (TE) and the relative inhibition light ratio (RILR) of BCPMW were significantly lowered from $0.08 \mathrm{mg} / \mathrm{L}$ to $0.02 \mathrm{mg} / \mathrm{L}$ and $36 \%$ to $9 \%$, respectively [88]. Tan et al. studied the degradation effect of $\mathrm{O}_{3} /$ PMS system on micropollutants containing a variety of anti-inflammatory drugs. Toxicity was calculated based on the toxicity parameter $50 \%$ lethal concentration (LC50) of each DBP. The results indicated that the toxicity of the system was decreased after $\mathrm{O}_{3} / \mathrm{PMS}$ pre-oxidation. Specifically, the toxicity of disinfection by-products (DBPs) reduced from $6.63 \times 10^{-2} \mathrm{~min}^{-1}$ to $5.27 \times 10^{-2} \mathrm{~min}^{-1}$ under neutral conditions [93].

Among the ROS generated in the $\mathrm{O}_{3} / \mathrm{PMS}$ system, ${ }^{\bullet} \mathrm{OH}$ and $\mathrm{SO}_{4}{ }^{\bullet-}$ have the strongest oxidizing ability. Therefore, the priority attack sites of these two free radicals should be firstly considered when analyzing the degradation path of micropollutants. $\mathrm{SO}_{4}{ }^{\bullet-}$ has electrophilicity and tends to react with electron-donating groups such as hydroxyl $(-\mathrm{OH})$, alkoxy $(-\mathrm{RO})$ and amino $\left(-\mathrm{NH}_{2}\right)$ groups, but does not easily react with the nitro $\left(-\mathrm{NO}_{2}\right)$, carbonyl $(\mathrm{C}=\mathrm{O})$, or other electron-withdrawing groups $[115,116]$. On the other hand, ${ }^{\bullet} \mathrm{OH}$ is nonselective toward organic pollutants in the oxidation reaction. For some examples, the aromatic ring or the side chains (isopropylamino and alkoxy) of PMT are likely to be attacked by ${ }^{\bullet} \mathrm{OH}$ and $\mathrm{SO}_{4}{ }^{\bullet-}$ mainly through addition to unsaturated carbon, $\mathrm{H}$-abstraction, and electron abstraction [15,117-119]. In addition, ${ }^{\bullet} \mathrm{OH}$ and $\mathrm{SO}_{4}{ }^{\bullet-}$ participated in the degradation of $A C E$ and the attack sites were $\mathrm{C}=\mathrm{C}, \mathrm{C}-\mathrm{O}$, and $\mathrm{C}-\mathrm{N}$ bonds [32]. 


\section{Formation and Control of OBPs during the $\mathrm{O}_{3} / \mathrm{PMS}$ System \\ 4.1. Formation Pathway and Influencing Factors}

The OBPs formed in the $\mathrm{O}_{3}$-based oxidation process are mainly low-molecular-weight carbonyls, organic halogenated OBPs, and inorganic OBPs. Among them, the inorganic OBPs generally includes chlorinated OBPs, brominated OBPs, and iodinated OBPs. Compared to brominated OBPs, the production of chlorinated and iodinated OBPs during the $\mathrm{O}_{3} /$ PMS system is negligible [65]. On the other hand, Frederik et al. reported the formation rule of $\mathrm{AOC}$ in $\mathrm{O}_{3}$ alone, but there is no relevant research on the $\mathrm{O}_{3} / \mathrm{PMS}$ system $[120,121]$. As typical brominated OBPs, the formation mechanism of bromate $\left(\mathrm{BrO}_{3}{ }^{-}\right)$in the treatment of bromide-containing water by $\mathrm{O}_{3}$ /PMS has been reported in detail by Wen et al., as shown in Figure 3 [64]. The interaction between bromide $\left(\mathrm{Br}^{-}\right)$and molecular $\mathrm{O}_{3},{ }^{\bullet} \mathrm{OH}$, and $\mathrm{SO}_{4}{ }^{\bullet-}$ in the $\mathrm{O}_{3} / \mathrm{PMS}$ system leads to the formation of $\mathrm{BrO}_{3}{ }^{-}[64,122,123]$. The $\mathrm{Br}^{-}$ would be oxidized into $\mathrm{Br}^{\bullet}$ by ${ }^{\bullet} \mathrm{OH}$ and $\mathrm{SO}_{4}{ }^{\bullet-}$, then $\mathrm{Br}^{\bullet}$ would transform into $\mathrm{BrO}{ }^{\bullet}$ by reacting with $\mathrm{O}_{3}$ and finally convert into $\mathrm{BrO}_{3}{ }^{-}$. Furthermore, $\mathrm{Br}^{-}$would react with $\mathrm{O}_{3}$ to produce hypobromous acid $\left(\mathrm{HOBr} / \mathrm{OBr}^{-}\right)$, which would also convert into $\mathrm{BrO} \mathrm{O}^{\bullet}$ by reacting with ${ }^{\bullet} \mathrm{OH}$ and $\mathrm{SO}_{4}{ }^{--}$[64]. Compared with the $\mathrm{BrO}_{3}{ }^{-}$generation path of the traditional ozone oxidation process, the $\mathrm{SO}_{4}{ }^{--}$path is added in the $\mathrm{O}_{3} / \mathrm{PMS}$ system. Therefore, the $\mathrm{O}_{3} / \mathrm{PMS}$ system will generate more $\mathrm{BrO}_{3}{ }^{-}$than $\mathrm{O}_{3}$ alone. In addition, the research by Liu et al. indicated that some brominated OBPs including dibromoacetaldehyde and tribromoacetaldehyde may possess much higher cytotoxicity than $\mathrm{BrO}_{3}{ }^{-}$[65]. Thus, more attention should be paid to the formation and control of organic halogenated OBPs during $\mathrm{O}_{3}$-based processes [124].
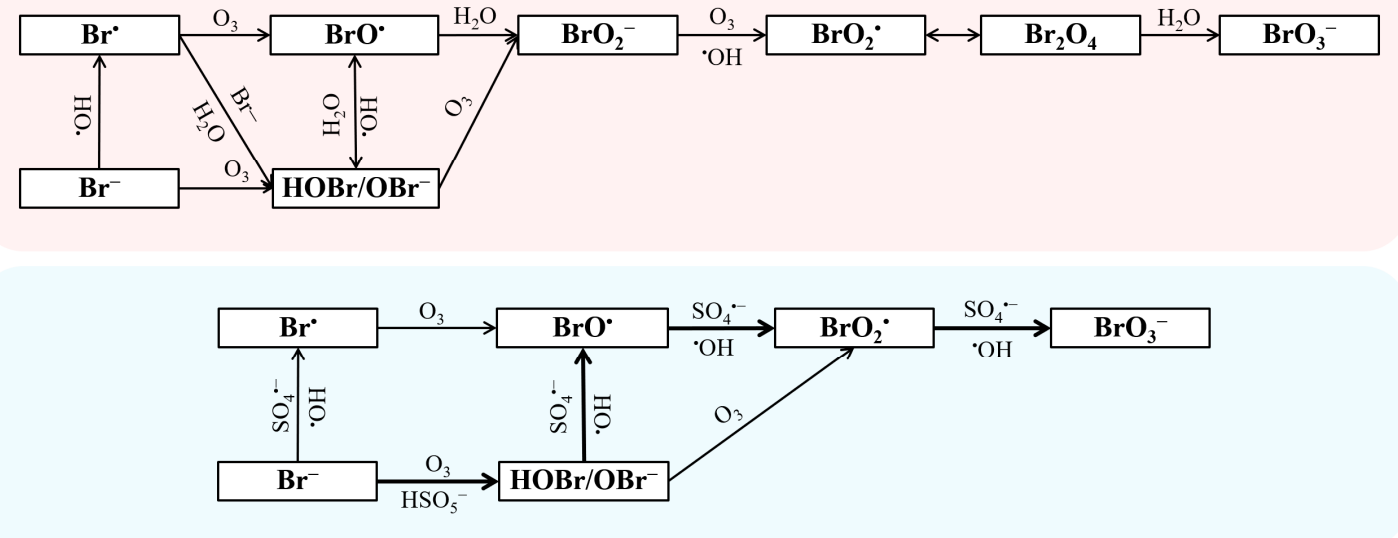

Figure 3. The mechanism of bromate formation (red: ozonation; blue: $\mathrm{O}_{3} / \mathrm{PMS}$ ). Reprinted with permission of refs. [64,124].

The influence of reaction conditions on the OBP formation is shown in Table 4. The amount of $\mathrm{BrO}_{3}^{-}$produced increases with the increase of $\mathrm{Br}^{-}$concentration within a certain range. However, too much $\mathrm{Br}^{-}$exhibits an inhibition effect [64]. The $\mathrm{pH}$ value of the solution comprehensively affects the formation of OBPs in the $\mathrm{O}_{3} / \mathrm{PMS}$ system by affecting $\mathrm{O}_{3}$ decomposition, $\mathrm{R}_{\mathrm{ct}, \bullet \mathrm{OH}}$ and $\mathrm{R}_{\mathrm{ct}, \mathrm{SO} 4} \bullet^{-}$, and PMS speciation [64,125]. According to the research results, $\mathrm{BrO}_{3}{ }^{-}$formation would increase as $\mathrm{O}_{3}$ and $\mathrm{PMS}$ dosage increases $[64,125,126]$. However, according to the reaction mechanism of the $\mathrm{O}_{3} / \mathrm{PMS}$ system, this promotion effect may be reduced with the addition of excessive $\mathrm{O}_{3}$ and PMS. The $\mathrm{HCO}_{3}-$ in the inorganic ions inhibits the formation of $\mathrm{BrO}_{3}-$ by scavenging free radicals. On the other hand, $\mathrm{NH}_{4}{ }^{+}$prevented the conversion of $\mathrm{Br}^{-}$into $\mathrm{BrO}_{3}{ }^{-}$by masking important intermediate products $\left(\mathrm{HOBr} / \mathrm{OBr}^{-}\right)$[64]. HA, as an important constituent of NOM, could scavenge ROS and thus reduce the formation of $\mathrm{BrO}_{3}{ }^{-}[78,127]$. In addition, HA could readily capture the intermediates, providing an additional inhibitory effect [122]. 
Table 4. The influence of reaction conditions on OBP formation.

\begin{tabular}{|c|c|c|}
\hline Influence Factor & Performance & Refs. \\
\hline The concentration of $\mathrm{Cl}^{-} / \mathrm{Br}^{-} / \mathrm{I}^{-}$ & $\begin{array}{l}\text { Excessive } \mathrm{Br}^{-} \text {would compete for reactive } \\
\text { substances, lowering the yield of } \mathrm{BrO}_{3}^{-} \text {. } \\
\text { The formation of iodinated OBPs increased with } \\
\text { the increase of } \mathrm{I}^{-} \text {concentration. }\end{array}$ & {$[64,65]$} \\
\hline $\mathrm{pH}$ & $\begin{array}{l}\text { The formation of } \mathrm{BrO}_{3}^{-} \text {was significantly } \\
\text { promoted with } \mathrm{pH} \text { increasing from } 4.0 \text { to } 10.0 \text {. } \\
\text { More available } \mathrm{Br}^{\bullet} \text { would be formed for further } \\
\text { oxidation to } \mathrm{BrO}^{\bullet} \text { at lower } \mathrm{pH} \text {. } \\
\text { The change of } \mathrm{pH} \text { values would affect } \\
\mathrm{HOBr} / \mathrm{OBr}^{-} \text {balance }(\mathrm{pKa}=8.8-9.0) \text {. }\end{array}$ & {$[64,92,125]$} \\
\hline $\mathrm{O}_{3}$ & $\begin{array}{l}\text { - } \mathrm{BrO}_{3}^{-} \text {formation was enhanced with the increase } \\
\text { in } \mathrm{O}_{3} \text { dosage. }\end{array}$ & [125] \\
\hline PMS & $\begin{array}{l}\text { - } \mathrm{BrO}_{3}^{-} \text {formation was enhanced with the increase } \\
\text { in PMS dosage. }\end{array}$ & [64] \\
\hline Inorganic ions & $\begin{array}{l}\text { - The presence of } \mathrm{HCO}_{3}^{-} \text {significantly reduced the } \\
\text { formation of } \mathrm{BrO}_{3}{ }^{-} \text {. } \\
\text { - } \mathrm{NH}_{4}^{+} \text {could mask } \mathrm{HOBr} / \mathrm{OBr}^{-} \text {into } \mathrm{NH}_{2} \mathrm{Br} \text {, thus } \\
\text { inhibited the formation of } \mathrm{BrO}_{3}{ }^{-} \text {. }\end{array}$ & {$[64]$} \\
\hline $\mathrm{NOM}$ & $\begin{array}{l}\text { - } \mathrm{HA} \text { could scavenge }{ }^{\bullet} \mathrm{OH}, \mathrm{SO}_{4}^{\bullet-} \text {, and molecular } \\
\mathrm{O}_{3} \text { to reduce the formation of } \mathrm{BrO}_{3}^{-} \text {. } \\
\mathrm{HA} \text { could capture the intermediates (i.e., } \mathrm{Br}^{\bullet} \text { and } \\
\mathrm{HOBr} / \mathrm{OBr}^{-} \text {), thus inhibiting the formation of } \\
\mathrm{BrO}_{3}^{-}\end{array}$ & {$[64]$} \\
\hline
\end{tabular}

\subsection{Control Strategy}

The current research on the control methods of OBP formation in the $\mathrm{O}_{3} / \mathrm{PMS}$ system focuses on inhibiting the formation of $\mathrm{BrO}_{3}{ }^{-}$. Several methods were used to control the formation of $\mathrm{BrO}_{3}{ }^{-}$in $\mathrm{O}_{3}$ alone: reducing $\mathrm{pH}$ [125], adding carbon materials [128,129], $\mathrm{H}_{2} \mathrm{O}_{2}$ [130], and ammonia $\left(\mathrm{NH}_{3}\right)$ and chlorine $\left(\mathrm{Cl}_{2}\right)[123,131]$. $\mathrm{pH}$ depression shifts the equilibrium of $\mathrm{HOBr} / \mathrm{OBr}^{-}$into $\mathrm{HOBr}(\mathrm{pKa}=8.8)$, thus slowing down the reaction between $\mathrm{HOBr} / \mathrm{OBr}^{-}$and $\mathrm{O}_{3}\left(\mathrm{k}_{(\mathrm{O} 3, \mathrm{HOBr})}=0.01 \mathrm{M}^{-1} \mathrm{~s}^{-1}, \mathrm{k}_{\left(\mathrm{O} 3, \mathrm{OBr}^{-}\right)}{ }^{-}=100 \mathrm{M}^{-1} \mathrm{~s}^{-1}\right)$, and finally reducing $\mathrm{BrO}_{3}{ }^{-}$formation. Besides, $\mathrm{pH}$ depression can lower the ${ }^{\bullet} \mathrm{OH}$ exposure, and thus inhibits the $\mathrm{BrO}_{3}{ }^{-}$formation from the oxidation pathways by ${ }^{\bullet} \mathrm{OH}$ [125]. Carbon materials suppress the $\mathrm{BrO}_{3}{ }^{-}$formation by reducing $\mathrm{HOBr} / \mathrm{OBr}^{-}$, which is crucial to the formation of $\mathrm{BrO}_{3}{ }^{-}$. [132]. $\mathrm{H}_{2} \mathrm{O}_{2}$ can inhibit $\mathrm{BrO}_{3}{ }^{-}$formation during ozonation because $\mathrm{H}_{2} \mathrm{O}_{2}$ can also reduce $\mathrm{HOBr} / \mathrm{OBr}^{-}$into $\mathrm{Br}^{-}\left(\mathrm{k}=7.6 \times 10^{8} \mathrm{M}^{-1} \mathrm{~s}^{-1}\right)$ [21,130]. Therefore, $\mathrm{BrO}_{3}{ }^{-}$formation is negligible in $\mathrm{O}_{3} / \mathrm{H}_{2} \mathrm{O}_{2}$ system with excess $\mathrm{H}_{2} \mathrm{O}_{2}$ [90]. In the pretreatment strategies of $\mathrm{NH}_{3}-\mathrm{Cl}_{2}$ and $\mathrm{Cl}_{2}-\mathrm{NH}_{3}, \mathrm{Br}^{-}$is mainly masked as bromine-containing haloamines (i.e., $\mathrm{NH}_{2} \mathrm{Br}, \mathrm{NHBr}_{2}$ and $\mathrm{NHBrCl}$ ) to inhibit the formation of $\mathrm{BrO}_{3}{ }^{-}[123,131]$.

At present, only Wen et al. have reported the control of $\mathrm{BrO}_{3}{ }^{-}$formation in the $\mathrm{O}_{3} /$ PMS system [92]. The research results indicated that the addition of carbon materials significantly inhibited the $\mathrm{BrO}_{3}{ }^{-}$formation, and the order of the inhibition efficiency was as follows: graphene $(\mathrm{GO})>$ carbon nano tube $(\mathrm{CNT})>$ powdered activated carbon (PAC). According to the study, the carbon materials could block the $\mathrm{BrO}_{3}{ }^{-}$formation by reducing $\mathrm{HOBr} / \mathrm{OBr}^{-}$in the reaction system [92]. Besides, Wen et al. synthesized a catalyst $\left(\mathrm{CuCo}_{2} \mathrm{O}_{4}-\mathrm{GO}\right)$, which could simultaneously inhibit the formation of $\mathrm{BrO}_{3}{ }^{-}$and enhance the degradation of micropollutants in the $\mathrm{O}_{3} / \mathrm{PMS}$ system. Specifically, when $100 \mathrm{mg} / \mathrm{L} \mathrm{CuCo}{ }_{2} \mathrm{O}_{4}-\mathrm{GO}$ was added, the $\mathrm{BrO}_{3}{ }^{-}$inhibition efficiency reached $96.17 \%$ and the degradation efficiency of SMX increased from $0.163 \mathrm{~min}^{-1}$ to $0.422 \mathrm{~min}^{-1}$ [133]. The pretreatment strategy (i.e., $\mathrm{NH}_{3}, \mathrm{Cl}_{2}-\mathrm{NH}_{3}$ and $\mathrm{NH}_{3}-\mathrm{Cl}_{2}$ ) was also used to inhibit $\mathrm{BrO}_{3}{ }^{-}$ generated in the $\mathrm{O}_{3} / \mathrm{PMS}$ system. All the pretreatment strategies reduced $90 \%$ or more of the overall $\mathrm{BrO}_{3}{ }^{-}$formation, while the $\mathrm{NH}_{3}-\mathrm{Cl}_{2}$ pretreatment strategy was prior to that of 
the $\mathrm{NH}_{3}$ and $\mathrm{Cl}_{2}-\mathrm{NH}_{3}$ [134]. The inhibitory effects of the common $\mathrm{BrO}_{3}{ }^{-}$control strategies, lowering $\mathrm{pH}$ and adding $\mathrm{H}_{2} \mathrm{O}_{2}$, in the $\mathrm{O}_{3} / \mathrm{PMS}$ system have not been studied yet. Many studies have reported that lowering $\mathrm{pH}$ could effectively inhibit the formation of $\mathrm{BrO}_{3}{ }^{-}$in an $\mathrm{O}_{3}$-only system. This is because the intermediate substance $\mathrm{HOBr} / \mathrm{OBr}^{-}(\mathrm{pKa}=8.8-9.0)$ exists in the form of $\mathrm{OBr}^{-}$under alkaline conditions, which is more likely to react with $\mathrm{O}_{3}$ to form $\mathrm{BrO}_{3}{ }^{-}[125,135,136]$. On the other hand, adding excess $\mathrm{H}_{2} \mathrm{O}_{2}$ could suppress the formation of $\mathrm{BrO}_{3}{ }^{-}$in $\mathrm{O}_{3}$ alone system by reducing $\mathrm{HOBr} / \mathrm{OBr}^{-}$to $\mathrm{Br}^{-}$[137-140]. These two kinds of $\mathrm{BrO}_{3}{ }^{-}$inhibition strategies may be able to inhibit the formation of $\mathrm{BrO}_{3}{ }^{-}$in the $\mathrm{O}_{3} / \mathrm{PMS}$ system through similar mechanisms. In general, as shown in Figure 4 , the control strategies are used to inhibit the formation of $\mathrm{BrO}_{3}{ }^{-}$by affecting the initial $\mathrm{Br}^{-}$or $\mathrm{HOBr} / \mathrm{OBr}^{-}$.

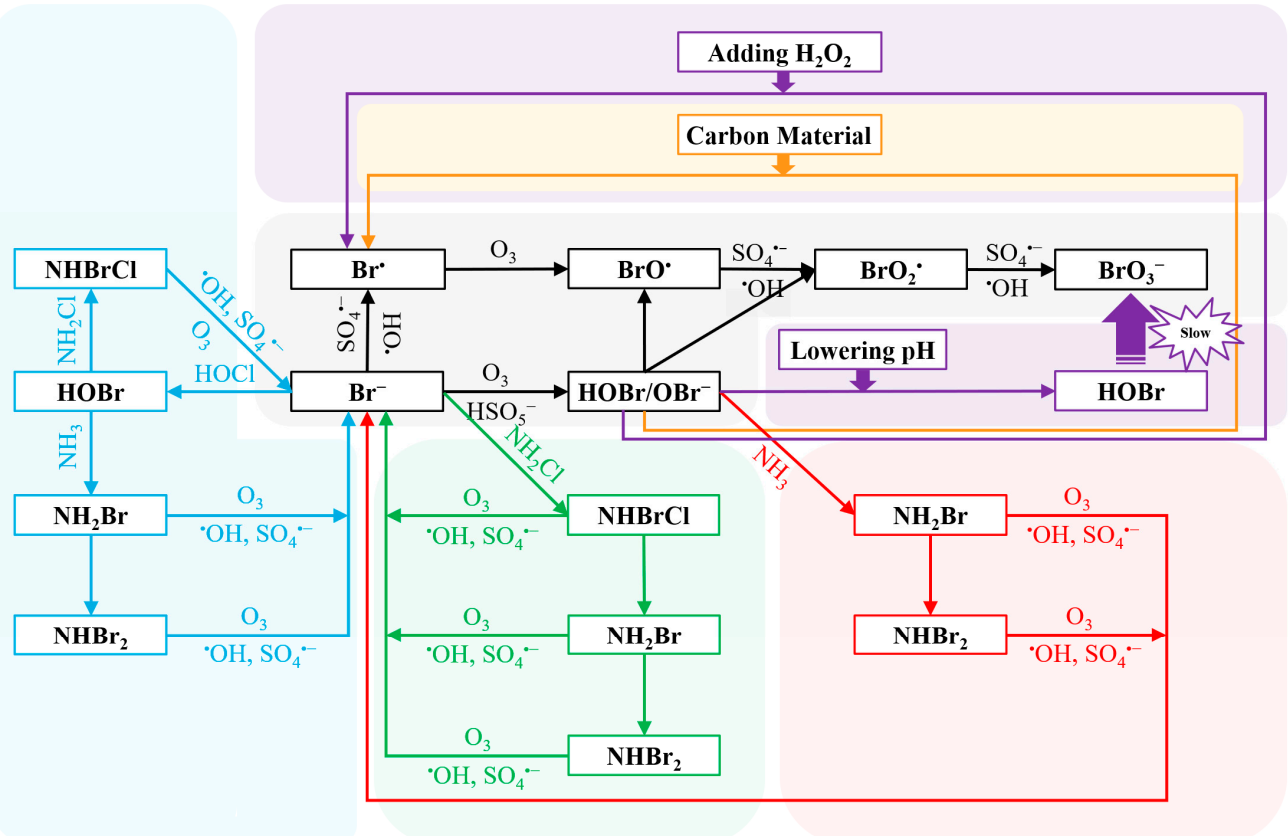

Figure 4. The mechanism of the inhibition of bromate formation (gray: bromate formation; orange: carbon materials; red: $\mathrm{NH}_{3}$; blue: $\mathrm{Cl}_{2}-\mathrm{NH}_{3}$; green: $\mathrm{NH}_{3}-\mathrm{Cl}_{2}$; violet: The bromate control strategies that have not been verified in the $\mathrm{O}_{3} /$ PMS system). Reprinted with permission $[64,92,133,134]$.

\section{Recommendations and Future Prospects}

In terms of micropollutant degradation, the research on the $\mathrm{O}_{3} / \mathrm{PMS}$ system is still at the laboratory level. The investigation using real water should be strengthened to reflect the feasibility of $\mathrm{O}_{3} /$ PMS system in practical applications, because many substances contained in actual water will affect the $\mathrm{O}_{3} / \mathrm{PMS}$ system. Besides, the degradation efficiency under different actual water conditions (i.e., surface water and groundwater) should be studied and comparable to explore the water quality condition which is suitable for the application of the $\mathrm{O}_{3} / \mathrm{PMS}$ system. At the same time, more pilot-scale research is needed to promote the conversion of $\mathrm{O}_{3} / \mathrm{PMS}$ system to practical applications.

Due to the generation of $\mathrm{SO}_{4}{ }^{\bullet-}$, the $\mathrm{O}_{3} / \mathrm{PMS}$ system has higher selectivity than the $\mathrm{O}_{3} / \mathrm{H}_{2} \mathrm{O}_{2}$ system. Therefore, the degradation rules of different types of micropollutants in the $\mathrm{O}_{3} / \mathrm{PMS}$ system should be extensively researched. The toxicity changes of the treated micropollutants also need to be studied, which are important indicators for evaluating the practical application potential of the $\mathrm{O}_{3} / \mathrm{PMS}$ system. In order to evaluate the advantages and disadvantages of the $\mathrm{O}_{3} / \mathrm{PMS}$ system and the suitable application conditions, the $\mathrm{O}_{3} /$ PMS system should be compared with the $\mathrm{O}_{3}$-alone and $\mathrm{O}_{3} / \mathrm{H}_{2} \mathrm{O}_{2}$ systems when conducting the above research. 
The formation rules of several kinds of OBPs under different conditions during the $\mathrm{O}_{3} /$ PMS system are not completely clear yet. Notable are the structure change of NOM and the formation rule of small molecular organic matter after treatment by $\mathrm{O}_{3} / \mathrm{PMS}$ system. At the same time, the effectiveness of various OBP control methods in the $\mathrm{O}_{3} / \mathrm{PMS}$ system has not been widely studied. Since the $\mathrm{O}_{3} / \mathrm{PMS}$ system can generate several kinds of ROS, the formation and control of the OBPs need to be compared with the $\mathrm{O}_{3}$ alone and $\mathrm{O}_{3} / \mathrm{H}_{2} \mathrm{O}_{2}$ systems to explore the mechanism. In addition, micropollutants are not fully mineralized by the $\mathrm{O}_{3} /$ PMS system but degraded into transformation products (TPs), which arouse a growing concern because of the unknown structures and potential biological effects. Therefore, more research needs to pay attention to the TPs formed during the degradation of micropollutants in the $\mathrm{O}_{3} / \mathrm{PMS}$ system.

The operational costs (e.g., energy consumption, chemical input), sustainability (e.g., resource use, carbon footprint), and general feasibility (e.g., physical footprint and oxidation by-product formation) of the $\mathrm{O}_{3} / \mathrm{PMS}$ system need to be studied to enable to compare their efficiency with other AOPs and alternative treatment processes (i.e., $\mathrm{O}_{3} / \mathrm{H}_{2} \mathrm{O}_{2}$, $\mathrm{O}_{3} / \mathrm{UV}$ ). In addition, the combination of $\mathrm{O}_{3}$ and biological activated carbon (BAC) is a very common water treatment process in practical applications, which can enhance the degradation efficiency of organic matter while reducing OBPs in the effluent. Therefore, the combined effect of $\mathrm{O}_{3} / \mathrm{PMS}$ and $\mathrm{BAC}$ is also worth studying.

\section{Conclusions}

As a new advanced oxidation process, $\mathrm{O}_{3}$ /PMS degrades many refractory micropollutants rapidly and effectively by generating many strong oxidizing ROS simultaneously. Compared with the widely used $\mathrm{O}_{3}$ and $\mathrm{O}_{3} / \mathrm{H}_{2} \mathrm{O}_{2}$ systems, the $\mathrm{O}_{3} /$ PMS system produces more types of free radicals and has higher selectivity. Based on the current research, the $\mathrm{O}_{3} /$ PMS system has a good degradation efficiency on general chemicals, agrochemicals and medical chemicals, and the degradation effect is affected by a variety of influencing factors (e.g., $\mathrm{pH}$, the concentration of $\mathrm{O}_{3}$ and $\mathrm{PMS}$, temperature, and inorganic ions). These factors mainly influence the $\mathrm{O}_{3}$ /PMS system by affecting the decomposition of $\mathrm{O}_{3}$, the activation of PMS, and the generation and conversion of free radicals. The generation and control of OBPs during the degradation of micropollutants in the $\mathrm{O}_{3} / \mathrm{PMS}$ system is another current research focus. According to the research results, the $\mathrm{BrO}_{3}{ }^{-}$produced in the $\mathrm{O}_{3} /$ PMS system is mainly due to the interaction between $\mathrm{Br}^{-}$and molecular $\mathrm{O}_{3},{ }^{\bullet} \mathrm{OH}$ and $\mathrm{SO}_{4}{ }^{\bullet-}$, and the $\mathrm{BrO}_{3}{ }^{-}$formation can be effectively inhibited by addition of carbon materials, or $\mathrm{NH}_{3}$ and $\mathrm{Cl}_{2}$ combined pretreatment strategy. However, it is not practical enough to apply the $\mathrm{O}_{3} / \mathrm{PMS}$ system to actual water treatment processes, and there are still many key problems that need to be addressed. Specifically, the degradation rule and toxicity change of different types of micropollutants in the $\mathrm{O}_{3} / \mathrm{PMS}$ system should be extensively studied. The formation rules of several kinds of OBPs during the $\mathrm{O}_{3} / \mathrm{PMS}$ system are not completely clear yet. Furthermore, pilot-scale research, the operational costs, sustainability, and general feasibility of the $\mathrm{O}_{3} / \mathrm{PMS}$ system also need to be studied. Currently, there is no integrated understanding of the $\mathrm{O}_{3} / \mathrm{PMS}$ system. It is expected that the findings of this review may advance future research and application of $\mathrm{O}_{3} / \mathrm{PMS}$ system. Specifically, the continuous exploration in the research directions proposed by this article will not only make the $\mathrm{O}_{3} /$ PMS system perform better in the degradation of micropollutants, but also enhance the potential of applications of the $\mathrm{O}_{3} / \mathrm{PMS}$ process in other areas such as sludge stabilization, dewatering, and inactivation of microorganisms.

Author Contributions: Z.L. (Zhao Liu): Investigation, Visualization, Writing-original draft; Z.L. (Zhiting Liang): Writing-Review and Editing; K.L.: Writing-Review and Editing; T.H.: Resources; J.M.: Formal analysis; G.W.: Conceptualization, Supervision, Funding acquisition. All authors have read and agreed to the published version of the manuscript. 
Funding: This research was supported by the National Natural Science Foundation of China (No. 51978557, 51678472), Shaanxi Science Fund for Distinguished Young Scholars (No. 2018JC-026), The Youth Innovation Team of Shaanxi Universities, and Shaanxi Provincial Key Research and Development Project (2020ZDLSF06-05).

Institutional Review Board Statement: Not applicable.

Informed Consent Statement: Not applicable.

Conflicts of Interest: The authors declare no conflict of interest.

\section{Nomenclatures}

$\begin{array}{ll}\text { Abbreviation } & \text { Full Name } \\ p C B A & \text { 4-chlorobenzoic acid } \\ \text { KET } & \text { Ketoprofen } \\ \text { ATZ } & \text { Atrazine } \\ \text { METR } & \text { Metronidazole } \\ \text { HA } & \text { Humic acid } \\ \text { PMT } & \text { Prometon } \\ 2,4-D & \text { 2,4-dichlorophenoxyacetic acid } \\ \text { MCFNs } & \text { CuFe } \mathrm{O}_{4} \text { magnetic nanoparticles } \\ \text { SMT } & \text { sulfamethazine } \\ \text { BCPMW } & \text { Biotreated Chinese patent medicine wastewater }(\text { e.g., cellulose, lignin, etc.) } \\ \text { ACE } & \text { Acesulfame } \\ \text { DEP } & \text { Diethyl phthalate } \\ \text { CN } & \text { Cyanide } \\ \text { BTA } & \text { Benzotriazole } \\ \text { ASA } & \text { Aspirin } \\ \text { CAP } & \text { Chloramphenicol } \\ \text { METO } & \text { Metoprolol } \\ \text { VEN } & \text { Venlafaxine } \\ \text { CBZ } & \text { Carbamazepine } \\ \text { MOX } & \text { Moxifloxacin } \\ \text { NB } & \text { Nitrobenzene } \\ \text { MeOH } & \text { Methanol } \\ \text { TBA } & \text { Tert-Butanol } \\ \text { BA } & \text { Benzoic acid } \\ \text { IPM } & \text { Iopamidol } \\ \text { MCFN } & \text { Magnetic copper ferrite nano-particle }\left(\mathrm{CuFe}_{2} \mathrm{O}_{4}\right) \\ \text { IBP } & \text { Ibuprofen } \\ \text { RBV } & \text { Ribavirin } \\ \text { OA } & \text { Oxalic acid } \\ \text { ATL } & \text { Atenolol } \\ \text { PNT } & \text { Phenacetin } \\ \text { SMX } & \text { Sulfamethoxazole } \\ & \end{array}$

\section{References}

1. Bilal, M.; Adeel, M.; Rasheed, T.; Zhao, Y.; Iqbal, H.M. Emerging contaminants of high concern and their enzyme-assisted biodegradation-A review. Environ. Int. 2019, 124, 336-353. [CrossRef] [PubMed]

2. Feng, G.; Huang, H.; Chen, Y. Effects of emerging pollutants on the occurrence and transfer of antibiotic resistance genes: A review. J. Hazard. Mater. 2021, 420, 126602. [CrossRef]

3. Patel, N.; Khan, Z.A.; Shahane, S.; Rai, D.; Chauhan, D.; Kant, C.; Chaudhary, V.K. Emerging Pollutants in Aquatic Environment: Source, Effect, and Challenges in Biomonitoring and Bioremediation-A Review. Pollution 2020, 6, 99-113.

4. Matzek, L.W.; Carter, K.E. Activated persulfate for organic chemical degradation: A review. Chemosphere 2016, 151, 178-188. [CrossRef]

5. Wacławek, S.; Lutze, H.V.; Grübel, K.; Padil, V.V.T.; Černík, M.; Dionysiou, D.D. Chemistry of persulfates in water and wastewater treatment: A review. Chem. Eng. J. 2017, 330, 44-62. [CrossRef]

6. Ushani, U.; Lu, X.; Wang, J.; Zhang, Z.; Dai, J.; Tan, Y. Sulfate radicals-based advanced oxidation technology in various en-vironmental remediation: A state-of-the-art review. Chem. Eng. J. 2020, 402, 126232. [CrossRef] 
7. Xia, Y.C.; Wan, Q.Q.; Xu, X.Q.; Cao, R.H.; Li, Y.F.; Wang, J.Y.; Xu, H.N.; Huang, T.L.; Wen, G. Solar disinfection of fungal spores in water: Kinetics, influencing factors, mechanisms and regrowth. Chem. Eng. J. 2022, 428, 132065. [CrossRef]

8. Hou, J.; He, X.; Zhang, S.; Yu, J.; Feng, M.; Li, X. Recent advances in cobalt-activated sulfate radical-based advanced oxidation processes for water remediation: A review. Sci. Total Environ. 2021, 770, 145311. [CrossRef]

9. Addison, F.; Offiong, N.-A.; Han, Q.; Wang, R.; Liu, N. Nitrogen-doped mesoporous carbon material (NCMK-3) as a catalyst for the removal of 4-chlorophenol during persulfate oxidation and its efficiency after reuse. Environ. Technol. 2020, 1-7. [CrossRef]

10. Yang, Y.; Jiang, J.; Lu, X.; Ma, J.; Liu, Y. Production of Sulfate Radical and Hydroxyl Radical by Reaction of Ozone with Per-oxymonosulfate: A Novel Advanced Oxidation Process. Environ. Sci. Technol. 2015, 49, 7330-7339. [CrossRef] [PubMed]

11. Deniere, E.; Alagappan, R.P.; Van Langenhove, H.; Van Hulle, S.; Demeestere, K. The ozone-activated peroxymonosulfate process $\left(\mathrm{O}_{3} / \mathrm{PMS}\right)$ for removal of trace organic contaminants in natural and wastewater: Effect of the (in)organic matrix composition. Chem. Eng. J. 2021, 133000. [CrossRef]

12. Huang, Y.; He, Z.; Liao, X.; Cheng, Y.; Qi, H. NDMA reduction mechanism of UDMH by $\mathrm{O}_{3} /$ PMS technology. Sci. Total Environ. 2022, 805, 150418. [CrossRef]

13. Li, S.; Huang, J.; Li, X.; Li, L. The relation of interface electron transfer and PMS activation by the H-bonding interaction between composite metal and MCM-48 during sulfamethazine ozonation. Chem. Eng. J. 2020, 398, 125529. [CrossRef]

14. Jaafarzadeh, N.; Ghanbari, F.; Ahmadi, M. Efficient degradation of 2,4-dichlorophenoxyacetic acid by peroxymonosulfate/magnetic copper ferrite nanoparticles/ozone: A novel combination of advanced oxidation processes. Chem. Eng. J. 2017, 320, 436-447. [CrossRef]

15. Wu, G.; Qin, W.; Sun, L.; Yuan, X.; Xia, D. Role of peroxymonosulfate on enhancing ozonation for micropollutant degradation: Performance evaluation, mechanism insight and kinetics study. Chem. Eng. J. 2019, 360, 115-123. [CrossRef]

16. Cong, J.; Wen, G.; Huang, T.; Deng, L.; Ma, J. Study on enhanced ozonation degradation of para-chlorobenzoic acid by peroxymonosulfate in aqueous solution. Chem. Eng. J. 2015, 264, 399-403. [CrossRef]

17. Gholikandi, G.B.; Zakizadeh, N.; Masihi, H. Application of peroxymonosulfate-ozone advanced oxidation process for simultaneous waste-activated sludge stabilization and dewatering purposes: A comparative study. J. Environ. Manag. 2018, 206, 523-531. [CrossRef] [PubMed]

18. Moreno-Andres, J.; Morillo-Ponce, J.; Ibáñez-López, M.E.; Acevedo-Merino, A.; García-Morales, J.L. Disinfection enhance-ment of single ozonation by combination with peroxymonosulfate salt. J. Environ. Chem. Eng. 2020, 8, 104335. [CrossRef]

19. Ike, I.A.; Karanfil, T.; Cho, J.; Hur, J. Oxidation byproducts from the degradation of dissolved organic matter by advanced oxidation processes-A critical review. Water Res. 2019, 164, 114929. [CrossRef]

20. Wu, Q.-Y.; Zhou, Y.-T.; Li, W.; Zhang, X.; Du, Y.; Hu, H.-Y. Underestimated risk from ozonation of wastewater containing bromide: Both organic byproducts and bromate contributed to the toxicity increase. Water Res. 2019, 162, 43-52. [CrossRef] [PubMed]

21. von Gunten, U. Ozonation of drinking water: Part II. Disinfection and by-product formation in presence of bromide, iodide or chlorine. Water Res. 2003, 37, 1469-1487. [CrossRef]

22. Ji, Y.; Ferronato, C.; Salvador, A.; Yang, X.; Chovelon, J.M. Degradation of ciprofloxacin and sulfamethoxazole by ferrous-activated persulfate: Implications for remediation of groundwater contaminated by antibiotics. Sci. Total Environ. 2014, 472, 800-808. [CrossRef] [PubMed]

23. van der Kooij, D. Assimilable organic carbon as an indicator of bacterial regrowth. J. Am. Water Works Assoc. 1992, 84, 57-65. [CrossRef]

24. Escobar, I.C.; Randall, A.A.; Taylor, J.S. Bacterial Growth in Distribution Systems: Effect of Assimilable Organic Carbon and Biodegradable Dissolved Organic Carbon. Environ. Sci. Technol. 2001, 35, 3442-3447. [CrossRef]

25. U.S. Environmental Protection Agency. National Primary Drinking Water Regulations: Stage 2 Disinfectants and Disinfection Byproducts Rule: Final Rule. Fed. Regist. 2006, 71, 388-493.

26. Jin, Y.; Chen, E.; Chen, C.; Zhang, X.; Chen, L. Standards for Drinking Water Quality (GB-5749-2006); Beijing Ministry of Health of the People's Republic of China: Bejing, China, 2006.

27. Edition, F. Guidelines for drinking-water quality. WHO Chrzonicle 2011, 38, 104-108.

28. Mazhar, M.A.; Khan, N.A.; Ahmed, S.; Khan, A.H.; Hussain, A.; Changani, F. Chlorination disinfection by-products in Mu-nicipal drinking water-A review. J. Clean. Prod. 2020, 273, 123159. [CrossRef]

29. Liu, X.; Chen, L.; Yang, M.; Tan, C.; Chu, W. The occurrence, characteristics, transformation and control of aromatic disinfection by-products: A review. Water Res. 2020, 184, 116076. [CrossRef] [PubMed]

30. Ghanbari, F.; Khatebasreh, M.; Mahdavianpour, M.; Lin, K.-Y.A. Oxidative removal of benzotriazole using peroxymonosulfate/ozone/ultrasound: Synergy, optimization, degradation intermediates and utilizing for real wastewater. Chemosphere 2020, 244, 125326. [CrossRef] [PubMed]

31. Ghanbari, F.; Moradi, M. Application of peroxymonosulfate and its activation methods for degradation of environmental organic pollutants: Review. Chem. Eng. J. 2017, 310, 41-62. [CrossRef]

32. Shao, Y.; Pang, Z.; Wang, L.; Liu, X. Efficient Degradation of Acesulfame by Ozone/Peroxymonosulfate Advanced Oxidation Process. Molecules 2019, 24, 2874. [CrossRef] [PubMed]

33. Li, Y.; Yuan, X.; Wang, D.; Wang, H.; Wu, Z.; Jiang, L.; Mo, D.; Yang, G.; Guan, R.; Zeng, G. Recyclable zero-valent iron acti-vating peroxymonosulfate synchronously combined with thermal treatment enhances sludge dewaterability by altering physicochemical and biological properties. Bioresour. Technol. 2018, 262, 294-301. [CrossRef] [PubMed] 
34. Chegini, Z.G.; Hassani, H.; Torabian, A.; Borghei, S.M. Enhancement of PMS activation in an UV/ozone process for cyanide degradation: A comprehensive study. Pigment Resin Technol. 2020, 49, 409-414. [CrossRef]

35. Jung, Y.; Hong, E.; Kwon, M.; Kang, J.-W. A kinetic study of ozone decay and bromine formation in saltwater ozonation: Effect of $\mathrm{O}_{3}$ dose, salinity, $\mathrm{pH}$, and temperature. Chem. Eng. J. 2017, 312, 30-38. [CrossRef]

36. Yuan, Z.; Sui, M.; Yuan, B.; Li, P.; Wang, J.; Qin, J.; Xu, G. Degradation of ibuprofen using ozone combined with peroxymonosulfate. Environ. Sci. Water Res. 2017, 3, 960-969.

37. Wang, Y.; Chu, W. Degradation of a xanthene dye by Fe(II)-mediated activation of Oxone process. J. Hazard. Mater. 2011, 186, 1455-1461. [CrossRef]

38. Sharma, J.; Mishra, I.; Dionysiou, D.; Kumar, V. Oxidative removal of Bisphenol A by UV-C/peroxymonosulfate (PMS): Kinetics, influence of co-existing chemicals and degradation pathway. Chem. Eng. J. 2015, 276, 193-204. [CrossRef]

39. Muthukumar, M.; Selvakumar, N. Studies on the effect of inorganic salts on decolouration of acid dye effluents by ozonation. Dye. Pigment. 2004, 62, 221-228. [CrossRef]

40. Lutze, H.V.; Kerlin, N.; Schmidt, T.C. Sulfate radical-based water treatment in presence of chloride: Formation of chlorate, inter-conversion of sulfate radicals into hydroxyl radicals and influence of bicarbonate. Water Res. 2015, 72, 349-360. [CrossRef]

41. Von Gunten, U. Ozonation of drinking water: Part I. Oxidation kinetics and product formation. Water Res. 2003, 37, $1443-1467$. [CrossRef]

42. Okawa, K.; Nakano, Y.; Nishijima, W.; Okada, M. Effects of humic substances on the decomposition of 2,4-dichlorophenol by ozone after extraction from water into acetic acid through activated carbon. Chemosphere 2004, 57, 1231-1235. [CrossRef] [PubMed]

43. Buffle, M.O.; von Gunten, U. Phenols and amine induced $\mathrm{HO}^{\bullet}$ generation during the initial phase of natural water ozonation. Environ. Sci. Technol. 2006, 40, 3057-3063. [CrossRef] [PubMed]

44. Chen, H.; Wang, J. Degradation and mineralization of ofloxacin by ozonation and peroxone $\left(\mathrm{O}_{3} / \mathrm{H}_{2} \mathrm{O}_{2}\right)$ process. Chemosphere 2021, 269, 128775. [CrossRef] [PubMed]

45. Guo, Y.; Zhao, E.; Wang, J.; Zhang, X.; Huang, H.; Yu, G.; Wang, Y. Comparison of emerging contaminant abatement by conventional ozonation, catalytic ozonation, $\mathrm{O}_{3} / \mathrm{H}_{2} \mathrm{O}_{2}$ and electro-peroxone processes. J. Hazard. Mater. 2020, $389,121829$. [CrossRef] [PubMed]

46. Von Sonntag, C.; Von Gunten, U. Chemistry of Ozone in Water and Wastewater Treatment: From Basic Principles to Applications; IWA Publishing: London, UK, 2012. [CrossRef]

47. Buxton, G.V.; Greenstock, C.L.; Helman, W.P.; Ross, A.B. Critical Review of rate constants for reactions of hydrated electrons, hydrogen atoms and hydroxyl radicals (.OH/.O_-In Aqueous Solution. J. Phys. Chem. Ref. Data 1988, 17, 513-886. [CrossRef]

48. Piras, F.; Santoro, O.; Pastore, T.; Pio, I.; De Dominicis, E.; Gritti, E.; Caricato, R.; Lionetto, M.; Mele, G. Controlling micropollutants in tertiary municipal wastewater by $\mathrm{O}_{3} / \mathrm{H}_{2} \mathrm{O}_{2}$, granular biofiltration and $\mathrm{UV} 254 / \mathrm{H}_{2} \mathrm{O}_{2}$ for potable reuse applications. Chemosphere 2020, 239, 124635. [CrossRef]

49. Staehelin, J.; Hoigne, J. Decomposition of ozone in water: Rate of initiation by hydroxide ions and hydrogen peroxide. Environ. Sci. Technol. 1982, 16, 676-681. [CrossRef]

50. Merényi, G.; Lind, J.; Naumov, S.; von Sonntag, C. Reaction of Ozone with Hydrogen Peroxide (Peroxone Process): A Revision of Current Mechanistic Concepts Based on Thermokinetic and Quantum-Chemical Considerations. Environ. Sci. Technol. 2010, 44, 3505-3507. [CrossRef]

51. Neta, P.; Huie, R.E.; Ross, A.B. Rate Constants for Reactions of Inorganic Radicals in Aqueous Solution. J. Phys. Chem. Ref. Data 1988, 17, 1027-1284. [CrossRef]

52. Lutze, H.V.; Bircher, S.; Rapp, I.; Kerlin, N.; Bakkour, R.; Geisler, M.; von Sonntag, C.; Schmidt, T.C. Degradation of chlo-rotriazine pesticides by sulfate radicals and the influence of organic matter. Environ. Sci. Technol. 2015, 49, 1673-1680. [CrossRef]

53. Gara, P.M.D.; Bosio, G.N.; Gonzalez, M.; Martire, D. Kinetics of the sulfate radical-mediated photo-oxidation of humic substances. Int. J. Chem. Kinet. 2007, 40, 19-24. [CrossRef]

54. Anipsitakis, G.P.; Dionysiou, D.D. Radical Generation by the Interaction of Transition Metals with Common Oxidants. Environ Sci. Technol. 2004, 38, 3705-3712. [CrossRef]

55. Guan, Y.-H.; Ma, J.; Li, X.-C.; Fang, J.-Y.; Chen, L.-W. Influence of pH on the Formation of Sulfate and Hydroxyl Radicals in the UV/Peroxymonosulfate System. Environ. Sci. Technol. 2011, 45, 9308-9314. [CrossRef] [PubMed]

56. Zhang, T.; Zhu, H.; Croué, J.-P. Production of Sulfate Radical from Peroxymonosulfate Induced by a Magnetically Separable $\mathrm{CuFe}_{2} \mathrm{O}_{4}$ Spinel in Water: Efficiency, Stability, and Mechanism. Environ. Sci. Technol. 2013, 47, 2784-2791. [CrossRef] [PubMed]

57. He, X.; de la Cruz, A.A.; Dionysiou, D.D. Destruction of cyanobacterial toxin cylindrospermopsin by hydroxyl radicals and sulfate radicals using UV-254nm activation of hydrogen peroxide, persulfate and peroxymonosulfate. J. Photochem. Photobiol. A Chem. 2013, 251, 160-166. [CrossRef]

58. Wang, J.; Wang, S. Activation of persulfate (PS) and peroxymonosulfate (PMS) and application for the degradation of emerging contaminants. Chem. Eng. J. 2018, 334, 1502-1517. [CrossRef]

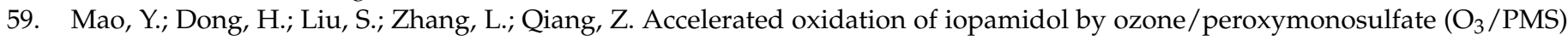
process: Kinetics, mechanism, and simultaneous reduction of iodinated disinfection by-product formation potential. Water Res. 2020, 173, 115615. [CrossRef] 
60. Deniere, E.; Van Hulle, S.; Van Langenhove, H.; Demeestere, K. Advanced oxidation of pharmaceuticals by the ozone-activated peroxymonosulfate process: The role of different oxidative species. J. Hazard. Mater. 2018, 360, 204-213. [CrossRef]

61. Yang, N.; Cui, J.; Zhang, L.; Xiao, W.; Alshawabkeh, A.N.; Mao, X. Iron electrolysis-assisted peroxymonosulfate chemical oxidation for the remediation of chlorophenol-contaminated groundwater. J. Chem. Technol. Biotechnol. 2016, 91, 938-947. [CrossRef]

62. Chen, Q.; Ji, F.; Liu, T.; Yan, P.; Guan, W.; Xu, X. Synergistic effect of bifunctional Co-TiO 2 catalyst on degradation of Rho-damine B: Fenton-photo hybrid process. Chem. Eng. J. 2013, 229, 57-65. [CrossRef]

63. Akbari, S.; Ghanbari, F.; Moradi, M. Bisphenol A degradation in aqueous solutions by electrogenerated ferrous ion activated ozone, hydrogen peroxide and persulfate: Applying low current density for oxidation mechanism. Chem. Eng. J. 2016, 294, 298-307. [CrossRef]

64. Wen, G.; Qiang, C.; Feng, Y.; Huang, T.; Ma, J. Bromate formation during the oxidation of bromide-containing water by ozone/peroxymonosulfate process: Influencing factors and mechanisms. Chem. Eng. J. 2018, 352, 316-324. [CrossRef]

65. Liu, X.; Hong, Y.; Ding, S.; Jin, W.; Dong, S.; Xiao, R.; Chu, W. Transformation of antiviral ribavirin during ozone/PMS in-tensified disinfection amid COVID-19 pandemic. Sci. Total Environ. 2021, 790, 148030. [CrossRef]

66. Das, T.N. Reactivity and Role of $\mathrm{SO}_{5}{ }^{\bullet-}$ Radical in Aqueous Medium Chain Oxidation of Sulfite to Sulfate and Atmospheric Sulfuric Acid Generation. J. Phys. Chem. A 2001, 105, 9142-9155. [CrossRef]

67. Matthew, B.M.; Anastasio, C. A chemical probe technique for the determination of reactive halogen species in aqueous solution: Part 1-Bromide solutions. Atmos. Chem. Phys. Discuss. 2006, 6, 2423-2437. [CrossRef]

68. Grebel, J.E.; Pignatello, J.J.; Mitch, W.A. Effect of Halide Ions and Carbonates on Organic Contaminant Degradation by Hydroxyl Radical-Based Advanced Oxidation Processes in Saline Waters. Environ. Sci. Technol. 2010, 44, 6822-6828. [CrossRef]

69. Hoigné, J. Chemistry of Aqueous Ozone and Transformation of Pollutants by Ozonation and Advanced Oxidation Processes. In Quality and Treatment of Drinking Water II. The Handbook of Environmental Chemistry (Part C: Water Pollution); Hrubec, J., Ed.; Springer: Berlin/Heidelberg, Germany, 1998; Volume 5, pp. 83-141.

70. Cao, Y.; Qiu, W.; Zhao, Y.; Li, J.; Jiang, J.; Yang, Y.; Pang, S.-Y.; Liu, G. The degradation of chloramphenicol by $\mathrm{O}_{3} / \mathrm{PMS}$ and the impact of $\mathrm{O}_{3}$-based AOPs pre-oxidation on dichloroacetamide generation in post-chlorination. Chem. Eng. J. 2020, 401, 126146. [CrossRef]

71. Sehested, K.; Holcman, J.; Bjergbakke, E.; Hart, E.J. Formation of ozone in the reaction of hydroxyl with $\mathrm{O}_{3}{ }^{-}$and the decay of the ozonide ion radical at pH 10-13. J. Phys. Chem. 1984, 88, 269-273. [CrossRef]

72. Maruthamuthu, P.; Neta, P. Radiolytic chain decomposition of peroxomonophosphoric and peroxomonosulfuric acids. J. Phys. Chem. 1977, 81, 937-940. [CrossRef]

73. Furman, O.S.; Teel, A.L.; Watts, R.J. Mechanism of Base Activation of Persulfate. Environ. Sci. Technol. 2010, 44, 6423-6428. [CrossRef] [PubMed]

74. Klaning, U.K.; Sehested, K.; Appelman, E.H. Laser flash photolysis and pulse radiolysis of aqueous solutions of the fluoroxysulfate ion, SO4F-. Inorg. Chem. 1991, 30, 3582-3584. [CrossRef]

75. Guo, L.; Zhong, Q.; Ding, J.; Lv, Z.; Zhao, W.; Deng, Z. Low-temperature NOx $(x=1,2)$ removal with $\bullet \mathrm{OH}$ radicals from catalytic ozonation over a $\mathrm{RGO}-\mathrm{CeO}_{2}$ nanocomposite: The highly promotional effect of oxygen vacancies. RSC Adv. 2016, 6, 87869-87877. [CrossRef]

76. Katsoyiannis, I.A.; Canonica, S.; von Gunten, U. Efficiency and energy requirements for the transformation of organic micropollutants by ozone, $\mathrm{O}_{3} / \mathrm{H}_{2} \mathrm{O}_{2}$ and $\mathrm{UV} / \mathrm{H}_{2} \mathrm{O}_{2}$. Water Res. 2011, 45, 3811-3822. [CrossRef] [PubMed]

77. Pisarenko, A.N.; Stanford, B.D.; Yan, D.; Gerrity, D.; Snyder, S.A. Effects of ozone and ozone/peroxide on trace organic contaminants and NDMA in drinking water and water reuse applications. Water Res. 2012, 46, 316-326. [CrossRef] [PubMed]

78. Elovitz, M.S.; Von Gunten, U.; Kaiser, H.-P. Hydroxyl Radical/Ozone Ratios during Ozonation Processes. II. The Effect of Temperature, pH, Alkalinity, and DOM Properties. Ozone Sci. Eng. 2000, 22, 123-150. [CrossRef]

79. Ikehata, K.; El-Din, M.G. Aqueous Pesticide Degradation by Ozonation and Ozone-Based Advanced Oxidation Processes: A Review (Part I). Ozone Sci. Eng. 2005, 27, 83-114. [CrossRef]

80. Yao, Y.; Xu, C.; Qin, J.; Wei, F.; Rao, M.; Wang, S. Synthesis of Magnetic Cobalt Nanoparticles Anchored on Graphene Nanosheets and Catalytic Decomposition of Orange II. Ind. Eng. Chem. Res. 2013, 52, 17341-17350. [CrossRef]

81. Shi, P.; Su, R.; Zhu, S.; Zhu, M.; Li, D.; Xu, S. Supported cobalt oxide on graphene oxide: Highly efficient catalysts for the removal of Orange II from water. J. Hazard. Mater. 2012, 229-230, 331-339. [CrossRef]

82. Beltrán, F.J.; Rivas, J.; Montero-De-Espinosa, R. Catalytic ozonation of oxalic acid in an aqueous TiO2 slurry reactor. Appl. Catal. B Environ. 2002, 39, 221-231. [CrossRef]

83. McElroy, W.J. A laser photolysis study of the reaction of sulfate(1-) with chloride and the subsequent decay of chlorine(1-) in aqueous solution. J. Phys. Chem. 1990, 94, 2435-2441. [CrossRef]

84. Wang, Z.; An, N.; Shao, Y.; Gao, N.; Du, E.; Xu, B. Experimental and simulation investigations of UV/persulfate treatment in presence of bromide: Effects on degradation kinetics, formation of brominated disinfection byproducts and bromate. Sep. Purif. Technol. 2020, 242, 116767. [CrossRef]

85. Yang, Y.; Pignatello, J.J.; Ma, J.; Mitch, W. Comparison of Halide Impacts on the Efficiency of Contaminant Degradation by Sulfate and Hydroxyl Radical-Based Advanced Oxidation Processes (AOPs). Environ. Sci. Technol. 2014, 48, 2344-2351. [CrossRef] [PubMed] 
86. Naumov, S.; Mark, G.; Jarocki, A.; von Sonntag, C. The reactions of nitrite ion with ozone in aqueous solution-new exper-imental data and quantum-chemical considerations. Ozone Sci. Eng. 2010, 32, 430-434. [CrossRef]

87. Morozov, P.A.; Ershov, B.G. The influence of phosphates on the decomposition of ozone in water: Chain process inhibition. Russ. J. Phys. Chem. A 2010, 84, 1136-1140. [CrossRef]

88. Tang, G.; Zhang, Y.; Wei, Y.; Wang, S.; Liu, P.; Jia, Z.; Yu, X.; Ma, F. Advanced treatment of bio-treated Chinese patent medicine wastewater using ozone/peroxymonosulfate-upflow biological aerated filter. Chem. Eng. J. 2020, 390, 124527. [CrossRef]

89. Yu, X.; Qin, W.; Yuan, X.; Sun, L.; Pan, F.; Xia, D. Synergistic mechanism and degradation kinetics for atenolol elimination via integrated UV/ozone/peroxymonosulfate process. J. Hazard. Mater. 2021, 407, 124393. [CrossRef] [PubMed]

90. Miklos, D.B.; Remy, C.; Jekel, M.; Linden, K.G.; Drewes, J.E.; Hübner, U. Evaluation of advanced oxidation processes for water and wastewater treatment-A critical review. Water Res. 2018, 139, 118-131. [CrossRef] [PubMed]

91. Wang, Y.; Xie, Y.; Sun, H.; Xiao, J.; Cao, H.; Wang, S. 2D/2D nano-hybrids of $\gamma-\mathrm{MnO} 2$ on reduced graphene oxide for catalytic ozonation and coupling peroxymonosulfate activation. J. Hazard. Mater. 2016, 301, 56-64. [CrossRef] [PubMed]

92. Wen, G.; Wang, S.; Wang, T.; Feng, Y.; Chen, Z.; Lin, W.; Huang, T.; Ma, J. Inhibition of bromate formation in the $\mathrm{O}_{3} / \mathrm{PMS}_{\mathrm{P}}$ process by adding low dosage of carbon materials: Efficiency and mechanism. Chem. Eng. J. 2020, 402, 126207. [CrossRef]

93. Tan, C.; Cui, X.; Sun, K.; Xiang, H.; Du, E.; Deng, L.; Gao, H. Kinetic mechanism of ozone activated peroxymonosulfate system for enhanced removal of anti-inflammatory drugs. Sci. Total Environ. 2020, 733, 139250. [CrossRef]

94. Wang, S.; Wang, J. Successive non-radical and radical process of peroxymonosulfate-based oxidation using various activation methods for enhancing mineralization of sulfamethoxazole. Chemosphere 2021, 263, 127964. [CrossRef]

95. Jung, H.; Choi, H. Catalytic decomposition of ozone and para-Chlorobenzoic acid (pCBA) in the presence of nanosized ZnO. Appl. Catal. B Environ. 2006, 66, 288-294. [CrossRef]

96. Real, F.J.; Benitez, F.J.; Acero, J.L.; Sagasti, J.J.P.; Casas, F. Kinetics of the Chemical Oxidation of the Pharmaceuticals Primidone, Ketoprofen, and Diatrizoate in Ultrapure and Natural Waters. Ind. Eng. Chem. Res. 2009, 48, 3380-3388. [CrossRef]

97. Acero, J.L.; Stemmler, K.; von Gunten, U. Degradation Kinetics of Atrazine and Its Degradation Products with Ozone and OH Radicals: A Predictive Tool for Drinking Water Treatment. Environ. Sci. Technol. 2000, 34, 591-597. [CrossRef]

98. Sanchez-Polo, M.; Rivera-Utrilla, J.; Prados-Joya, G.; García, M.; Ángeles, F.; Bautista-Toledo, I. Removal of pharmaceutical compounds, nitroimidazoles, from waters by using the ozone/carbon system. Water Res. 2008, 42, 4163-4171. [CrossRef] [PubMed]

99. Lian, L.; Yao, B.; Hou, S.; Fang, J.; Yan, S.; Song, W. Kinetic Study of Hydroxyl and Sulfate Radical-Mediated Oxidation of Pharmaceuticals in Wastewater Effluents. Environ. Sci. Technol. 2017, 51, 2954-2962. [CrossRef] [PubMed]

100. Benner, J.; Ternes, T.A. Ozonation of Metoprolol: Elucidation of Oxidation Pathways and Major Oxidation Products. Environ. Sci. Technol. 2009, 43, 5472-5480. [CrossRef] [PubMed]

101. Benitez, F.J.; Acero, J.L.; Real, F.J.; Roldán, G. Ozonation of pharmaceutical compounds: Rate constants and elimination in various water matrices. Chemosphere 2009, 77, 53-59. [CrossRef] [PubMed]

102. Santoke, H.; Song, W.; Cooper, W.J.; Peake, B.M. Advanced oxidation treatment and photochemical fate of selected anti-depressant pharmaceuticals in solutions of Suwannee River humic acid. J. Hazard. Mater. 2012, 217, 382-390. [CrossRef] [PubMed]

103. Lee, Y.; Kovalova, L.; McArdell, C.S.; von Gunten, U. Prediction of micropollutant elimination during ozonation of a hospital wastewater effluent. Water Res. 2014, 64, 134-148. [CrossRef] [PubMed]

104. McDowell, D.C.; Huber, M.M.; Wagner, M.; von Gunten, U.; Ternes, T.A. Ozonation of Carbamazepine in Drinking Water: Identification and Kinetic Study of Major Oxidation Products. Environ. Sci. Technol. 2005, 39, 8014-8022. [CrossRef] [PubMed]

105. Matta, R.; Tlili, S.; Chiron, S.; Barbati, S. Removal of carbamazepine from urban wastewater by sulfate radical oxidation. Environ. Chem. Lett. 2010, 9, 347-353. [CrossRef]

106. Hoigné, J.; Bader, H. Rate constants of reactions of ozone with organic and inorganic compounds in water-II: Dissociating organic compounds. Water Res. 1983, 17, 185-194. [CrossRef]

107. Oh, W.-D.; Dong, Z.; Lim, T.-T. Generation of sulfate radical through heterogeneous catalysis for organic contaminants removal: Current development, challenges and prospects. Appl. Catal. B Environ. 2016, 194, 169-201. [CrossRef]

108. Liang, C.; Su, H.-W. Identification of Sulfate and Hydroxyl Radicals in Thermally Activated Persulfate. Ind. Eng. Chem. Res. 2009, 48, 5558-5562. [CrossRef]

109. Toth, J.E.; Rickman, K.A.; Venter, A.R.; Kiddle, J.J.; Mezyk, S.P. Reaction Kinetics and Efficiencies for the Hydroxyl and Sulfate Radical Based Oxidation of Artificial Sweeteners in Water. J. Phys. Chem. A 2012, 116, 9819-9824. [CrossRef]

110. Shu, Z.; Bolton, J.R.; Belosevic, M.; El Din, M.G. Photodegradation of emerging micropollutants using the medium-pressure $\mathrm{UV} / \mathrm{H} 2 \mathrm{O} 2$ Advanced Oxidation Process. Water Res. 2013, 47, 2881-2889. [CrossRef]

111. Ma, J.; Graham, N.J. Degradation of atrazine by manganese-catalysed ozonation: Influence of humic substances. Water Res. 1999, 33, 785-793. [CrossRef]

112. Lau, T.K.; Chu, W.; Graham, N.J.D. The Aqueous Degradation of Butylated Hydroxyanisole by UV $/ \mathrm{S}_{2} \mathrm{O}_{8}{ }^{2-}$ : Study of Reaction Mechanisms via Dimerization and Mineralization. Environ. Sci. Technol. 2007, 41, 613-619. [CrossRef]

113. Xie, P.; Ma, J.; Liu, W.; Zou, J.; Yue, S.; Li, X.; Wiesner, M.R.; Fang, J. Removal of 2-MIB and geosmin using UV/persulfate: Contributions of hydroxyl and sulfate radicals. Water Res. 2015, 69, 223-233. [CrossRef]

114. Zuo, Z.; Cai, Z.; Katsumura, Y.; Chitose, N.; Muroya, Y. Reinvestigation of the acid-base equilibrium of the (bi)carbonate radical and $\mathrm{pH}$ dependence of its reactivity with inorganic reactants. Radiat. Phys. Chem. 1999, 55, 15-23. [CrossRef] 
115. Yang, S.; Yang, X.; Shao, X.; Niu, R.; Wang, L. Activated carbon catalyzed persulfate oxidation of Azo dye acid orange 7 at ambient temperature. J. Hazard. Mater. 2011, 186, 659-666. [CrossRef]

116. Wen, G.; Wang, S.-J.; Ma, J.; Huang, T.-L.; Liu, Z.-Q.; Zhao, L.; Su, J.-F. Enhanced ozonation degradation of di-n-butyl phthalate by zero-valent zinc in aqueous solution: Performance and mechanism. J. Hazard. Mater. 2014, 265, 69-78. [CrossRef] [PubMed]

117. Antoniou, M.G.; de la Cruz, A.A.; Dionysiou, D.D. Intermediates and reaction pathways from the degradation of micro-cystin-LR with sulfate radicals. Environ. Sci. Technol. 2010, 44, 7238-7244. [CrossRef] [PubMed]

118. Méndez-Díaz, J.; Sánchez-Polo, M.; Rivera-Utrilla, J.; Canonica, S.; von Gunten, U. Advanced oxidation of the surfactant SDBS by means of hydroxyl and sulphate radicals. Chem. Eng. J. 2010, 163, 300-306. [CrossRef]

119. Song, W.; Yan, S.; Cooper, W.J.; Dionysiou, D.D.; O'Shea, K.E. Hydroxyl radical oxidation of cylindrospermopsin (cyano-bacterial toxin) and its role in the photochemical transformation. Environ. Sci. Technol. 2012, 46, 12608-12615. [CrossRef] [PubMed]

120. Hammes, F.; Salhi, E.; Köster, O.; Kaiser, H.P.; Egli, T.; Von Gunten, U. Mechanistic and kinetic evaluation of organic disin-fection by-product and assimilable organic carbon (AOC) formation during the ozonation of drinking water. Water Res. 2006, 40, 2275-2286. [CrossRef]

121. Hammes, F.; Meylan, S.; Salhi, E.; Köster, O.; Egli, T.; Von Gunten, U. Formation of assimilable organic carbon (AOC) and specific natural organic matter (NOM) fractions during ozonation of phytoplankton. Water Res. 2007, 41, 1447-1454. [CrossRef]

122. Fang, J.-Y.; Shang, C. Bromate Formation from Bromide Oxidation by the UV/Persulfate Process. Environ. Sci. Technol. 2012, 46, 8976-8983. [CrossRef] [PubMed]

123. Von Gunten, U; Hoigne, J. Bromate Formation during Ozonization of Bromide-Containing Waters: Interaction of Ozone and Hydroxyl Radical Reactions. Environ. Sci. Technol. 1994, 28, 1234-1242. [CrossRef]

124. Fischbacher, A.; Löppenberg, K.; von Sonntag, C.; Schmidt, T.C. A New Reaction Pathway for Bromite to Bromate in the Ozonation of Bromide. Environ. Sci. Technol. 2015, 49, 11714-11720. [CrossRef]

125. Yang, J.; Li, J.; Dong, W.; Ma, J.; Yang, Y.; Li, J.; Yang, Z.; Zhang, X.; Gu, J.; Xie, W.; et al. Enhancement of bromate formation by $\mathrm{pH}$ depression during ozonation of bromide-containing water in the presence of hydroxylamine. Water Res. 2017, 109, 135-143. [CrossRef]

126. Legube, B.; Parinet, B.; Gelinet, K.; Berne, F.; Croue, J.-P. Modeling of bromate formation by ozonation of surface waters in drinking water treatment. Water Res. 2004, 38, 2185-2195. [CrossRef] [PubMed]

127. Naumov, S.; von Sonntag, C. Standard Gibbs free energies of reactions of ozone with free radicals in aqueous solution: Quantumchemical calculations. Environ. Sci. Technol. 2011, 45, 9195-9204. [CrossRef] [PubMed]

128. Bao, M.L.; Griffini, O.; Santianni, D.; Barbieri, K.; Burrini, D.; Pantani, F. Removal of bromate ion from water using granular activated carbon. Water Res. 1999, 33, 2959-2970. [CrossRef]

129. Huang, W.-J.; Cheng, Y.-L. Effect of characteristics of activated carbon on removal of bromate. Sep. Purif. Technol. 2008, 59, 101-107. [CrossRef]

130. Yang, J.; Dong, Z.; Jiang, C.; Wang, C.; Liu, H. An overview of bromate formation in chemical oxidation processes: Occurrence, mechanism, influencing factors, risk assessment, and control strategies. Chemosphere 2019, 237, 124521. [CrossRef]

131. Ling, L.; Deng, Z.; Fang, J.; Shang, C. Bromate control during ozonation by ammonia-chlorine and chlorine-ammonia pretreatment: Roles of bromine-containing haloamines. Chem. Eng. J. 2020, 389, 123447. [CrossRef]

132. Huang, X.; Zhou, X.; Zhou, J.; Huang, Z.; Liu, S.; Qian, G.; Gao, N. Bromate inhibition by reduced graphene oxide in ther-mal/PMS process. Water Res. 2017, 122, 701-707. [CrossRef] [PubMed]

133. Liu, Z.; Wang, S.; Ma, W.; Wang, J.; Xu, H.; Li, K.; Huang, T.; Ma, J.; Wen, G. Adding $\mathrm{CuCo}_{2} \mathrm{O}_{4}-\mathrm{GO}$ to inhibit bromate formation and enhance sulfamethoxazole degradation during the ozone/peroxymonosulfate process: Efficiency and mechanism. Chemosphere 2022, 286, 131829. [CrossRef] [PubMed]

134. Liu, Z.; Wen, G.; Ni, Y.; Wang, S.; Wang, S.; Yu, Y.; Huang, T.; Ma, J. Inhibition of bromate formation in the ozone/peroxymonosulfate process by ammonia, ammonia-chlorine and chlorine-ammonia pretreatment: Comparisons with ozone alone. Sep. Purif. Technol. 2022, 278, 119600. [CrossRef]

135. Zehavi, D.; Rabani, J. Oxidation of aqueous bromide ions by hydroxyl radicals. Pulse radiolytic investigation. J. Phys. Chem. 1972, 76, 312-319. [CrossRef]

136. Zuo, J.; Xu, X.; Wan, Q.; Cao, R.; Liang, Z.; Xu, H.; Li, K.; Huang, T.; Wen, G.; Ma, J. Inactivation of fungal spores in water with peracetic acid: Efficiency and mechanism. Chem. Eng. J. 2022, 427, 131753. [CrossRef]

137. Hoigné, J.; Bader, H. The role of hydroxyl radical reactions in ozonation processes in aqueous solutions. Water Res. 1976, 10, 377-386. [CrossRef]

138. Von Gunten, U.; Bruchet, A.; Costentin, E. Bromate formation in advanced oxidation processes. J. Am. Water Work. Assoc. 1996, 88, 53-65. [CrossRef]

139. Wang, L.; Jing, K.; Hu, B.; Lu, J. Hydrogen peroxide suppresses the formation of brominated oxidation by-products in heatactivated peroxydisulfate oxidation process. Chem. Eng. J. 2021, 417, 129138. [CrossRef]

140. Wan, Q.Q.; Cao, R.H.; Wen, G.; Xu, X.Q.; Xia, Y.C.; Wu, G.H.; Li, Y.F.; Wang, J.Y.; Lin, Y.Z.; Huang, T.L. Sequential use of UV-LEDs irradiation and chlorine to disinfect waterborne fungal spores: Efficiency, mechanism and photoreactivation. J. Hazard. Mater. 2022, 423, 127102. [CrossRef] 